\title{
LESÃO VIRTUAL CAUSADA PELA MANCHA DE Alternaria helianthi EM DIFERENTES GENÓTIPOS DE GIRASSOL (Helianthus annuus L.), E SUA RELAÇÃO COM A FOTOSSÍNTESE
}

\author{
Nuria Pereira Calvet \\ Engenheira Agrônoma
}

Orientador: Prof. Dr. RICARdo FeRRAz de OliveIRA

\begin{abstract}
Dissertação apresentada à Escola Superior de Agricultura "Luiz de Queiroz", Universidade de São Paulo, para a obtenção do título de Mestre em Ciências, Área de Concentração: Fisiologia e Bioquímica de Plantas.
\end{abstract}

P I R A C I C A B A

Estado de São Paulo - Brasil

Outubro - 2001 


\title{
Dados Internacionais de Catalogação na Publicação (CIP)
} DIVISÃO DE BIBLIOTECA E DOCUMENTAÇÃO - ESALQ/USP

\author{
Calvet, Nuria Pereira \\ Lesão virtual causada pela mancha de Alternaria helianthi em diferentes genótipos \\ de girassol (Helianthus annuus L.), e sua relação com a fotossítense / Nuria Pereira \\ Calvet. - Piracicaba, 2001. \\ 48 p. : il. \\ Dissertação (mestrado) - Escola Superior de Agricultura Luiz de Queiroz, 2001. \\ Bibliografia. \\ 1. Fisiologia vegetal 2. Fotossíntese 3. Fungo fitopatogênico 4. Girassol 5. \\ Mancha-de-alternaria 6. Patógeno 7. Vetor de doença I. Título
}

CDD 633.39

"Permitida a copia total ou parcial deste documento, desde que citada a fonte - $\mathrm{O}$ autor" 
AOS MEUS PAIS, OFEREÇO

A SHIRLEY, DEDICO 


\section{AGRADECIMENTOS}

Agradeço à Deus pela natureza tão perfeita que concebeu.

A Dra. Maria Regina G. Ungaro - IAC, pela amizade, pela dedicação e atenção em me auxiliar nos trabalhos, pelos ensinamentos e orientação.

Aos funcionários e estagiários da Seção de Plantas Oleaginosas - IAC, Amarildo, Vera, Antonia, Rosa, Lourdes, Zenildo, Tomás e Fábio, pela grande ajuda nos experimentos em campo e pelo ótimo ambiente de trabalho no qual convivemos.

Ao Prof. Dr. Ricardo F. de Oliveira - ESALQ, pela orientação e amizade nesta caminhada.

Aos funcionários do Horto Experimental da Botânica - ESALQ, Francisco e José Francisco, pela grande ajuda nos trabalhos em casa de vegetação.

Ao Prof. Dr. Carlos Alberto Labate - ESALQ, pelas idéias para o desenvolvimento dos trabalhos.

Ao Dr. Sérgio A. Moraes da Seção de Fitopatologia - IAC, pelo auxílio nos trabalhos com a Alternaria.

Ao Dr. Luiz Alberto Ambrósio - IAC, pelo auxílio com as análises estatísticas.

A Dra. Regina Maria V. B. Leite do CNPSo - EMBRAPA, pelos inóculos de Alternaria.

À ESALQ - USP pela oportunidade de fazer parte desta familia; ao IAC pelo apoio logístico dado à execução deste trabalho; à CAPES pela concessão da bolsa de estudos e à FAPESP pelo apoio ao projeto de pesquisa. 


\section{SUMÁRIO}

Página

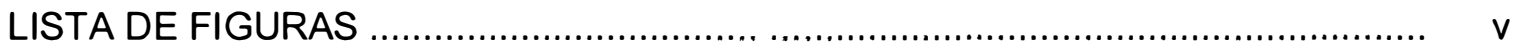

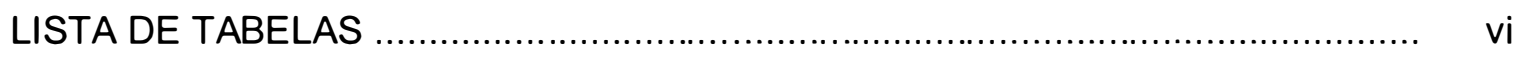

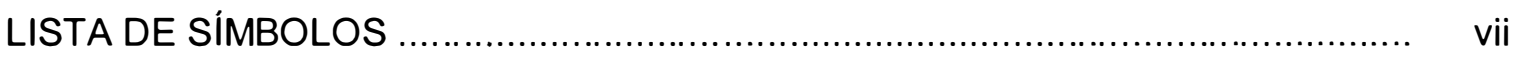

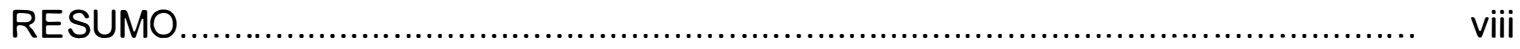

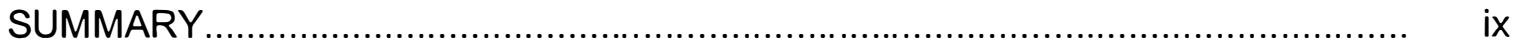

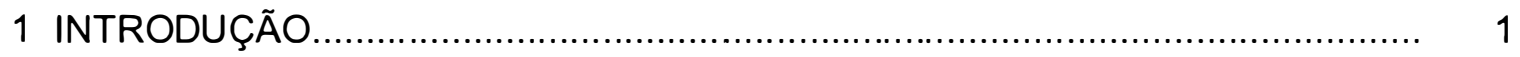

2 REVISÃO DE LITERATURA................................................................. 4

3 MATERIAL E MÉTODOS..................................................................... 8

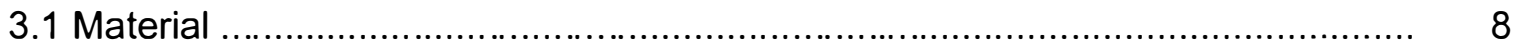

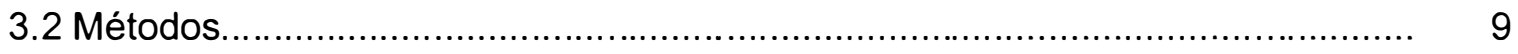

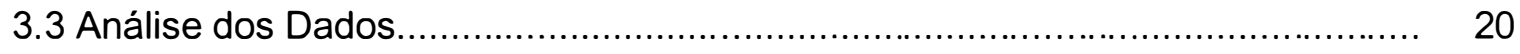

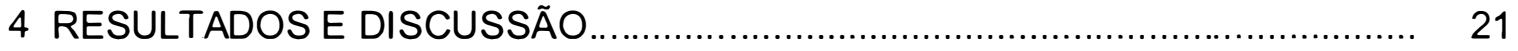

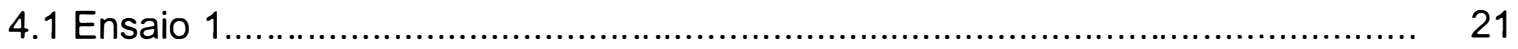

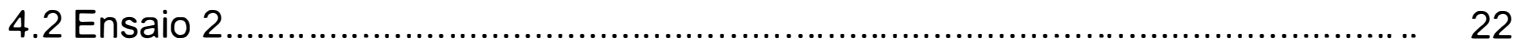

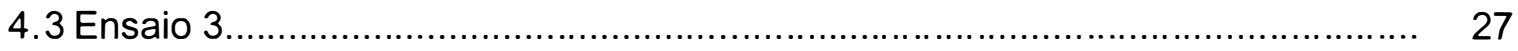

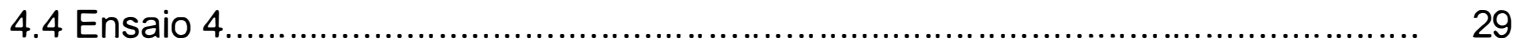

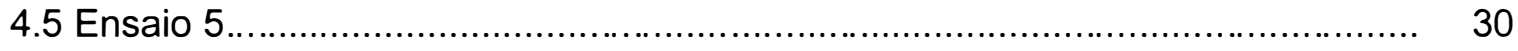

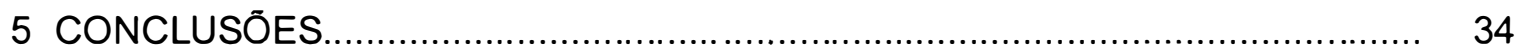

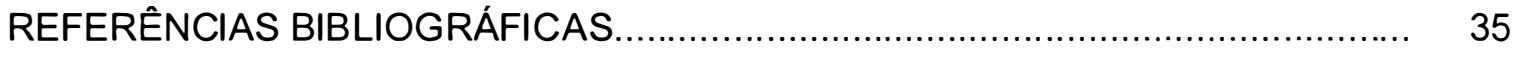

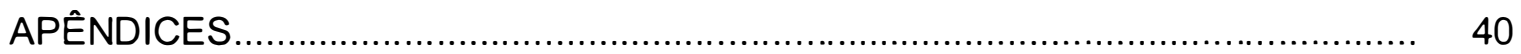




\section{LISTA DE FIGURAS}

Página

1 Sistema Li-6400 medidor portátil de fotossintese, console ...................... 12

2 Sistema LI-6400 detalhe da câmara sensora ...................................... 12

3 Programa WinDIAS, seleção da área de interesse na imagem.................... 19

4 Programa WinDIAS, seleção das áreas sadias e doentes......................... 19

5 Programa WinDIAS, cálculo das áreas e porcentagem de área doente....... 20

6 Curva de saturação para os genótipos de girassol estudados..................... 22 


\section{LISTA DE TABELAS}

1a Horário de início das medidas realizadas no Ensaio 2, primeira

Página

avaliação

1b Horário de início das medidas realizadas no Ensaio 2, segunda avaliação

2 Taxa de fotossintese líquida (A) em $\mu \mathrm{mol} \mathrm{CO}_{2} \mathrm{~m}^{-2} \mathrm{~s}^{-1}$ em função da FFF

3a Valores médios da A dos tratamentos sem doença e com doença, e a redução causada na fotossintese, Ensaio 2, primeira avaliação

3b Valores médios da A dos tratamentos sem doença e com doença, e a redução causada na fotossíntese, Ensaio 2, segunda avaliação

4 Valores médios da $\mathrm{A}$ e a produção de grãos $\left(\mathrm{kg} \mathrm{ha}^{-1}\right)$, para os genótipos de girassol, Ensaio 2, segunda avaliação

5a Valores encontrados para o parâmetro $\beta$, para o patossistema Girassol $x$ Alternaria, medidas realizadas no Ensaio 2, primeira avaliação ....

5b Valores encontrados para o parâmetro $\beta$, para o patossistema Girassol x Alternaria, medidas realizadas no Ensaio 2, segunda avaliação .........

6 Valores médios da A dos tratamentos sem doença e com doença, e a redução causada na fotossintese, Ensaio 3

7 Valores encontrados para o parâmetro $\beta$, para o patossistema Girassol $x$ Alternaria. Medidas realizadas no Ensaio 3

8 Valores médios da A obtidos nos estratos superior, mediano e inferior dos genótipos avaliados e respectivos coeficientes de variação .............

9 Valores médios da (A), para folhas sadias e doentes, medida nas plantas do tratamento com doença 


\title{
LISTA DE SÍMBOLOS
}

\author{
A Taxa da assimilação líquida em $\mu \mathrm{mol} \mathrm{m} \mathrm{m}^{-2} \mathrm{~s}^{-1}$ \\ $\beta \quad$ Parâmetro que expressa a relação entre os componentes virtual e visual \\ EUR Eficiência no uso da radiação \\ FFF Fluxo de fótons fotossintéticos \\ Px Fotossíntese medida nas plantas doentes \\ Po Fotossintese medida nas plantas sadias \\ x Severidade da doença
}




\title{
LESÃO VIRTUAL CAUSADA PELA MANCHA DE Alternaria helianthi EM DIFERENTES GENÓTIPOS DE GIRASSOL (Helianthus annuus L.), E SUA RELAÇÃO COM A FOTOSSÍNTESE
}

\author{
Autora: Nuria Pereira Calvet \\ Orientador: Prof. Dr. Ricardo Ferraz de Oliveira
}

\section{RESUMO}

A mancha de Alternaria causada pelo fungo Alternaria helianthi, é uma das doenças com maior potencial de dano na cultura do girassol no Brasil, uma vez que as condições climáticas favoráveis ao seu desenvolvimento coincidem com as principais épocas de plantio desta cultura. Considerando-se a importância da fotossíntese para as plantas, os patógenos podem interferir, inicialmente causando clorose, até atingir grandes áreas foliares com lesões necróticas, levando à perda de tecido e à desfolha. Para quantificar os efeitos da doença em folhas de girassol, foi medida a taxa de fotossintese líquida $(A)$ de folhas sadias e de folhas doentes durante o ciclo de crescimento da cultura, em duas épocas distintas de plantio. Através de uma equação matemática, a severidade da doença foi relacionada à fotossintese $(\beta)$. Analisou-se, para o patossistema Girassol x Alternaria, a influência do patógeno nas áreas verdes remanescentes do tecido foliar. Foi observada redução das taxas fotossintéticas dos tecidos verdes remanescentes das folhas doentes, comprovando-se que existe lesão virtual para o patossistema Girassol x Alternaria. Os valores de $\beta$ encontrados variaram de 1,4 a 4,7 , indicando que as épocas de plantio têm influência sobre a severidade da doença. Observou-se que folhas ainda sem lesões de plantas doentes apresentaram comprometimento fotossintético. 


\title{
VIRTUAL LESION CAUSED BY Alternaria helianthi BLIGHTS IN DIFFERENT SUNFLOWER (Helianthus annuus L.) GENOTYPES, AND ITS RELATION WITH THE PHOTOSYNTHESIS
}

\author{
Author: Nuria Pereira Calvet \\ Adviser: Prof. Dr. Ricardo Ferraz de Oliveira
}

\section{SUMMARY}

The Alternaria blights in sunflower caused by the fungus Alternaria helianthi is one of the major diseases that affects sunflower in Brazil. The effects of them upon net photosynthetic rate of four different sunflower genotypes leaves were measured in the field. Alternaria blights reduced photosynthesis not only through a reduction in green leaf area, but also through an effect on photosynthesis of the remaining green leaf tissue. A mathematics approach was derived to relate the infected leaf area with net photosynthetic rate $(\beta)$. This relationship was used to analyse the pathosystem Sunflower x Alternaria. For all genotypes studied, a decrease in the photosynthetic rates of infected leaves was observed when compared to healthy leaves. In addition, reduction in photosynthesis was observed in the remaining green leaf tissue of infected plants proving the existence of virtual lesions in sunflower leaves when infected by Alternaria helianthi. Values of $\beta$ ranged from 1,4 to 4,7, showing that season of planting has a strong influence upon severity of the disease. 


\section{INTRODUÇÃO}

A radiação solar, interceptada pela área foliar verde, e a eficiência no uso da radiação, são os fatores que determinam a produção de matéria seca e, consequentemente, a produção econômica das culturas. Encontra-se na literatura que a colonização da planta por um patógeno pode causar redução na capacidade fotossintética do hospedeiro devido à destruição de tecido verde e redução na interceptação da radiação solar; contudo, não são discutidos os efeitos deletérios aos tecidos adjacentes não lesionados, ou mesmo, mudanças que possam ocorrer no processo fotossintético.

Alguns patógenos causam redução na taxa fotossintética, em função das fitotoxinas que produzem. Muitos autores têm relatado que as células fotossintetizantes de hospedeiros, em áreas não colonizadas da folha, podem ser afetadas por estas toxinas, alterando o metabolismo da área foliar verde remanescente.

Estimativas confiáveis dos prejuizos causados pelos patógenos constituem um pré-requisito para o desenvolvimento de um programa bem sucedido de controle integrado de doenças, independente do método a ser utilizado. A quantificação do 'dano' é um importante fator que vem sendo considerado nos tradicionais Sistemas de Manejo Integrado; mas a lógica da relação entre severidade da doença e dano é incerta.

Esta incerteza se deve aos seguintes fatos: a severidade da doença considerada isoladamente tem efeito diferente caso ocorra precoce ou tardiamente numa cultura; a desfolha nem sempre é considerada; a área foliar das plantas é ignorada; e, finalmente, porque a fisiologia nos ensina que produção depende da área sadia, verde, fotossintetizante das folhas e não da área doente e necrosada destruída pelo patógeno (Bastiaans, 1991; Bergamin et al, 1995). 
Com o objetivo de integrar as observações de severidade da doença, e suas implicações na fotossintese do hospedeiro, iniciaram-se pesquisas com uma visão fisiopatológica do problema, as quais evoluíram para o conceito de lesão virtual, que relaciona fotossintese foliar com a área de uma lesão virtual, que é maior ou igual à área da lesão visível.

Bastiaans (1991), propõe uma classificação dos patógenos de acordo com sua capacidade de afetar a eficiência no uso da radiação de seu hospedeiro. Este conceito é baseado na relação entre lesão visual (proporção de área foliar visualmente doente) e lesão virtual (proporção de área foliar não visualmente doente, que pode ser igual ou maior que a área foliar visualmente doente). À partir deste conceito, foi desenvolvido um modelo matemático que relaciona a taxa de fotossintese líquida $(\boldsymbol{A})$ na área foliar doente, comparando com a $\boldsymbol{A}$ da área foliar sadia e a severidade da doença. $A$ determinação experimental de $\beta$ é obtida através da equação 1 , que descreve os efeitos simultâneos do patógeno na área fotossintética e a atividade fotossintética da área remanescente:

$$
P_{x} / P_{0}=(1-x)^{\beta}
$$

Sendo:

$\left(\mathbf{P}_{\mathbf{x}} / \mathbf{P}_{\mathrm{o}}\right)$ a lesão virtual :

$\left(\mathbf{P}_{\mathbf{x}}\right)$ a fotossintese medida nas folhas de plantas doentes;

$\left(P_{0}\right)$ a fotossintese medida nas folhas de plantas sadias;

$(1$ - x) a lesão visual :

( $\mathbf{x}$ ) a severidade da doença, e

$\beta$ a relação entre os componentes virtual e visual. 
Exemplificando, valores de $\beta$ menores que a unidade $(1,0)$ indicam que a eficiência no uso da radiação (EUR) não é afetada pelo patógeno; assim sendo, valores maiores que a unidade indicam reduções na EUR e existência da lesão virtual para o patossistema em estudo.

Apesar da importância deste estudo para a proteção de plantas, são escassos os trabalhos que envolvem o modelo de Bastiaans. Este trabalho de pesquisa propõe o estudo da influência de um patógeno, enquanto causador de lesões em folhas, na taxa fotossintética do girassol, tendo como objetivos definir o desempenho fotossintético de folhas de girassol quando infectadas por Alternaria helianthi e verificar a possibilidade de genótipos distintos apresentarem respostas fotossintéticas diferentes à infecção. Com a referida metodologia, as avaliações das taxas de fotossintese dos tecidos sadios e doentes foram realizadas utilizando um medidor portátil de fotossíntese, e as áreas foliares sadias e doentes foram determinadas com o auxílio de um programa para processamento de imagens. 


\section{REVISÃO DE LITERATURA}

A radiação solar interceptada pela área foliar verde e a eficiência do uso desta radiação, são os fatores responsáveis pela produção de matéria seca e, consequentemente, da produção de grãos pelas plantas (Monteith, 1981), o que torna o processo fotossintético muito importante para o entendimento do potencial produtivo de uma cultura. Apesar da grande importância, pouco é conhecido sobre o efeito de patógenos na fotossíntese (Lucas, 1998).

Um dos principais efeitos das doenças na redução da produção das culturas é o da redução na interceptação de luz pelas folhas, resultante de uma menor área foliar fotossinteticamente ativa, em decorrência da queda das folhas ou devido às manchas necróticas que cobrem a superfície foliar, resultado da ação de um fungo necrotrófico ou hemibiotrófico (Waggoner \& Berger, 1987; Madeira et al., 1988).

A mancha de alternaria, causada pelo patógeno Alternaria helianthi, é uma das mais importantes doenças do girassol em muitas partes do mundo (Kong et al., 1997). Trata-se de um fungo necrotrófico, ou seja, mata as células dos hospedeiros para obtenção de nutrientes, causando lesões nas folhas e nas hastes, morte das plântulas e podridão nos capítulos (Sackston, 1981; Allen et al., 1983a). As lesões são arredondadas, necróticas, de coloração marrom escuro com halo clorótico, que levam à seca e ao desfoliamento.

Esta doença é particularmente destrutiva em regiões tropicais e subtropicais, visto que os fatores que mais influenciam a severidade são as condições climáticas. A combinação de altas temperaturas (entre 25 e $30^{\circ} \mathrm{C}$ ) e umidade relativa do ar acima de $70 \%$ acelera o desenvolvimento da enfermidade, a qual se pode tornar muito agressiva (Prasad \& Singh, 1983; Carson, 1985; Kong et al., 1997; Dudienas et al., 1998). 
Moraes et al. (1983), testaram a patogenicidade de $A$. helianthi em genótipos de girassol e encontraram respostas diferenciadas quanto à susceptibilidade; enquanto nos cultivares IAC-Uruguai e IAC-Anhandy houve o desenvolvimento do fungo mais intensamente nas folhas inferiores, no cultivar VNIIMK o patógeno causou morte de todas as plantas inoculadas.

Além disso, o fungo produz a deoxiradicinina, um metabólito secundário (Tal et al., 1985), que é tóxico e pode afetar processos celulares importantes, prejudicando a fotossintese e o rendimento da cultura (Paul et al.,1990).

Segundo Leite \& Pascholati (1995), Agrios (1997) e Lucas (1998), o primeiro sintoma, causado por fungos necrotróficos nas folhas, é a clorose. Este quadro evolui, podendo haver destruição de organelas, como os cloroplastos, pela ação de enzimas degradadoras e pela produção de metabólitos tóxicos pelo fungo, durante a infecção. Goodman et al. (1986), citados por Stangarlin (1999), comentam igualmente, que doenças fúngicas que resultam em sintomas de necrose, parecem influenciar 0 processo fotossintético, por afetar inicialmente os cloroplastos, o que resultaria na degeneração da clorofila e na redução da fixação do $\mathrm{CO}_{2}$.

Para vários patossistemas, os efeitos do patógeno na fotossintese da área foliar verde remanescente têm sido relatados. Um dos primeiros, data do ano de 1965, quando Goto relatou que perdas na produção de arroz, devido ao brusone, excederam as perdas na produção causada pelo corte de certa porcentagem de área foliar igual à porcentagem de área foliar coberta pela doença. Esta redução extra indicaria que a doença influenciou o hospedeiro mais que a simples perda da área foliar.

Dunaway (1971), com tomate infectado por Fusarium lycopersici e Tzeng (1985), em estudo conduzido com algodão infectado por Verticilium dahliae Kleb., mostraram reduções na condutância estomática e no potencial hídrico foliar das plantas. A redução na condutância estomática reduz a concentração de $\mathrm{CO}_{2}$ no interior da folha, provocando alterações na fotossintese. Esta situação pode resultar da produção e secreção de toxinas que são difundidas ao redor da área das lesões visuais, as quais afetariam o metabolismo da clorofila, bem como inibiriam a atividade das enzimas do Ciclo de Calvin. 
Waggoner \& Berger (1987) comentam que muitas tentativas para determinar a relação entre produção da cultura e severidade das doenças têm sido frustradas. A lógica dessa correlação é dominada por fatores como a determinação de quanto as doenças estão realmente afetando a fotossíntese das plantas, uma vez que a produção de matéria seca depende desse processo.

Em busca de soluções para o problema, Bastiaans (1991), em trabalho realizado com Piricularia oryzae, agente causal de brusone no arroz, observou que as folhas atingidas pela doença reduziram a $A$ não apenas pela redução da área foliar verde, mas também por efeito nas áreas verdes remanescentes. Uma função foi derivada para relacionar a taxa de fotossintese líquida na área foliar doente comparada com a fotossintese da área foliar sadia e a severidade da doença. Esta função é baseada na premissa de que a lesão visual é parte de uma lesão virtual onde a fotossintese é nula ou pouco significativa.

Na interação Puccinia coronata - aveia, Scholes \& Rolfe (1995) observaram que a fotossintese apresentava variações em diferentes regiões da folha infectada, sendo que o maior declínio ocorria nas áreas colonizadas pelo fungo e áreas adjacentes, quando comparadas com folhas sadias. No patossistema $A$. cândida $\times A$. thaliana, Chou et al. (1995) mostraram que nas áreas da folha em que o fungo estava presente, havia redução na taxa fotossintética, acúmulo de carboidratos e perda de amido e clorofila, enquanto que em áreas adjacentes o efeito no metabolismo também se fazia notar, mas com menor intensidade.

Kempenaar et al. (1996), estudando o efeito da necrose foliar causada por Ascochyta caulina na fotossintese das folhas de $C$. album $L$., através de um modelo de três parâmetros, constataram que a taxa fotossintética líquida das folhas diminuiu com o aumento das lesões necróticas, indicando que as necroses dos tecidos foliares afetaram fortemente os tecidos sadios ao redor das lesões.

Bassanezi et al. (1997), em estudos realizados com antracnose do feijoeiro, encontraram um valor para $\beta$ de 7,24. Este valor indica que a antracnose do feijoeiro reduz a eficiência fotossintética não apenas do tecido lesionado, mas também em parte do tecido verde remanescente das folhas infectadas. 
Em trabalho realizado com o patossistema Xanthomonas campestris pv. oryzae em arroz, Elings et al. (1999) propuseram medir a extensão da lesão virtual a fim de verificar os efeitos das lesões foliares nas trocas de $\mathrm{CO}_{2}$. Entre os resultados obtidos, a fotossintese máxima (obtida sob condições de luminosidade saturante) sofreu redução maior do que a esperada pelas lesões visuais.

Estudos do efeito fisiológico de Verticillium dahliae em girassol, constataram redução na fotossíntese foliar e demonstraram correlação positiva entre perdas na produção de grãos e redução na área foliar (Robb et al., 1979; Sadras et al., 2000).

Os patógenos foliares Uromyces appendiculatus, Puccinia griseola e Colletotrichum lindemuthianum, agentes causais, respectivamente, de ferrugem, mancha angular e antracnose do feijoeiro, causaram alterações na fotossintese, respiração e transpiração das plantas, à partir dos primeiros sintomas das doenças por eles causados. A redução foi tanto em função da diminuição da área foliar verde pelas lesões, como pela redução da eficiência fotossintética nas áreas foliares remanescentes. As alterações causadas tiveram reflexo na produção. Isto pode ser explicado pela incorporação do valor de $\beta$ no cálculo da severidade da doença (Bassanezi, 2000). 


\section{MATERIAL E MÉTODOS}

Os experimentos foram conduzidos no Núcleo Experimental de Campinas, pertencente ao Instituto Agronômico - IAC, localizado no referido município e assim caracterizado : $22^{\circ} 54^{\prime} \mathrm{S}, 47^{\circ} 05^{\prime} \mathrm{E}$; solo latossolo roxo eutrófico, horizonte A moderado e textura argilosa ( $(\mathrm{Re}$ ), altitude $674 \mathrm{~m}$. Foram feitas medidas da taxa de fotossintese líquida e quantificadas as alterações relacionadas às trocas gasosas nas folhas de girassol, em decorrência da alternariose. Folhas sadias e folhas doentes foram medidas.

O ensaio para determinação da curva de luz dos genótipos, foi realizado na casa de vegetação do Departamento de Ciências Biológicas, pertencente à ESALQ USP, localizado no município de Piracicaba - SP. Foram feitas medidas para determinação do ponto de saturação lumínica, através das curvas de resposta a diferentes intensidades de luz.

\subsection{MATERIAL}

\subsubsection{Genótipos utilizados}

Foram utilizados 4 genótipos de girassol (Helianthus annuus L.), com as seguintes características de sensibilidade à doença:

a) IAC-IARAMA: selecionado para menor sensibilidade à alternaria, ciclo precoce;

b) IAC-URUGUAI: foi escolhido por ter sido observado boa resistência à alternaria em vários ensaios realizados anteriormente, ciclo tardio; 
c) RUMBOSOL 91: foi escolhido por ter apresentado alta incidência da doença nos ensaios nacionais de competição de cultivares realizados no IAC, ciclo tardio;

d) BRS 191: híbrido recém lançado pela EMBRAPA, bastante sensivel à alternaria; nos ensaios realizados tem apresentado alta produção de grãos e alto teor de óleo, ciclo precoce.

\subsection{MÉTODOS}

Os ensaios em campo experimental foram delineados em um esquema fatorial 4 × 2, com 4 genótipos e 2 tratamentos - COM DOENÇA e SEM DOENÇA, com 4 repetições, totalizando 32 parcelas (Apêndice 1).

O campo foi semeado em duas épocas distintas. A escolha das épocas baseouse nos trabalhos de Sentelhas et al. (1996) e Dudienas et al. (1998), que encontraram respostas consistentes do desenvolvimento do fungo relacionado diretamente às condições climáticas, sendo os plantios de outubro - novembro os mais favoráveis ao desenvolvimento do patógeno enquanto os realizados entre maio e agosto, mostraramse menos favoráveis.

Foram acrescentados, ao planejamento inicial, dois outros ensaios, que contemplaram observações importantes e interessantes, que podem ajudar a explicar as interações Girassol x Alternaria. As observações foram feitas nas mesmas parcelas do Ensaio 2.

a) Ensaio 1: estudo da saturação lumínica dos genótipos utilizados

b) Ensaio 2 (época das águas): plantio no início de setembro de 2000, época favorável ao aparecimento da doença, com as medições iniciadas em outubro.

c) Ensaio 3 (época da seca): plantio em meados de junho de 2001, época desfavorável ao aparecimento da doença, com as medições iniciadas em agosto.

d) Ensaio 4: medidas em folhas sadias e doentes na mesma planta. 
e) Ensaio 5: medidas em folhas de diferentes estratos de uma mesma planta sadia.

\subsubsection{Cultivo do patógeno em laboratório e inoculações}

Para os ensaios realizados em setembro/2000 e junho/2001, foi utilizado um isolado de $A$. helianthi obtido junto à EMBRAPA - CNPSo, que foi multiplicado e repicado na Sessão de Fitopatologia do IAC.

Os isolados foram colocados para crescer em meio aveia-dextrose-agar, por ser um meio que favorece o crescimento e a esporulação (Srinivas et al., 1997), à temperatura de $25^{\circ} \mathrm{C}\left(+/-1^{\circ} \mathrm{C}\right)$, no escuro. Após 15 dias de incubação, as colônias atingiram de 3,0 a $4,5 \mathrm{~cm}$ de diâmetro, quando então foram repicadas em tubos de ensaio contendo o mesmo meio de crescimento, e colocadas para esporular sob iluminação de lâmpadas fluorescentes de $40 \mathrm{~W}$ (à $30 \mathrm{~cm}$ de distância dos tubos de ensaio), à temperatura de $25^{\circ} \mathrm{C}\left(+/-1^{\circ} \mathrm{C}\right)$, durante 15 dias. As colônias formadas apresentaram coloração verde-escura característica, bom crescimento e boa esporulação.

A suspensão para inoculação foi preparada com água destilada, na concentração de $1 \times 10^{4}$ esporos $\mathrm{ml}^{-1}$ e $0,05 \%$ de Tween 80 . A concentração foi ajustada após contagem dos esporos de $A$. helianthi em câmara de Neubauer.

Nos dois ensaios realizados no campo experimental, as parcelas correspondentes ao tratamento com doença foram inoculadas aos 30 dias após a emergência; os primeiros sintomas visíveis surgiram aproximadamente $12 \mathrm{~h}$ após a inoculação. Transcorrida uma semana após a inoculação, as plantas apresentaram lesões variando entre $0,3-0,5 \mathrm{~cm}$ de diâmetro, tamanho adequado para serem iniciadas as medições de trocas gasosas. 


\subsubsection{Avaliação das trocas gasosas}

O parâmetro determinado foi a assimilação de $\mathrm{CO}_{2}$, realizado com o auxílio do aparelho Medidor Portátil de Fotossintese modelo LI-6400 fabricado pela LI-COR ${ }^{\circledR}$, Nebrasca/USA.

Trata-se de um sistema portátil que permite, através de medidas das trocas gasosas, quantificar instantaneamente a taxa de consumo de $\mathrm{CO}_{2}$ de um tecido foliar. O instrumento é composto de um console (Figura 1) e uma câmara ventilada de $6 \mathrm{~cm}^{2}$ (Figura 2), onde é colocada a parte da folha a ser analisada. No console estão a bomba de sucção, reservatório de ar, válvula de ajuste, medidor de fluxo de massa de ar, controlador interno de fluxo e um microprocessador, que possui a função de processar e armazenar dados. $\mathrm{Na}$ câmara ventilada está o ventilador, o sensor de $\mathrm{CO}_{2}$ e umidade, um termopar de referência e outro que toca a face inferior da folha (Long \& Hallgren, 1993). 


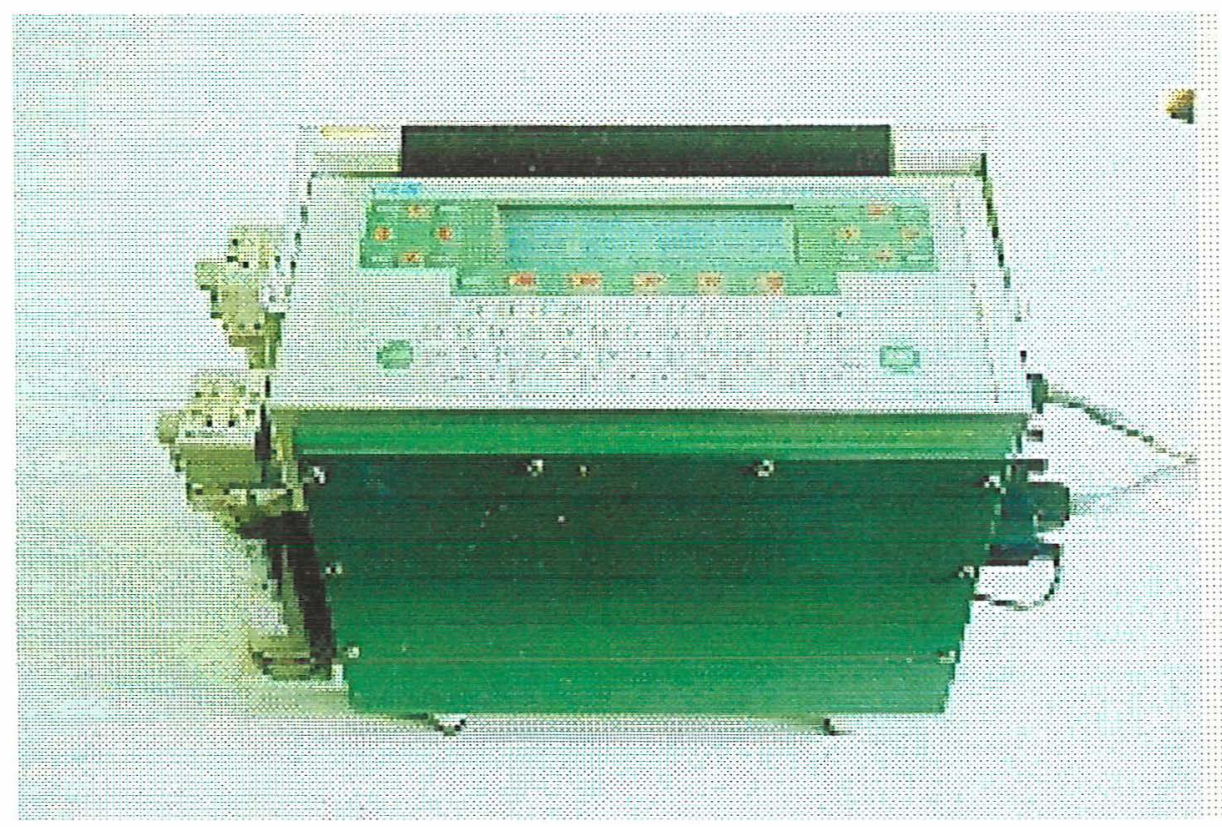

Figura 1 - Sistema LI - 6400, console portátil.

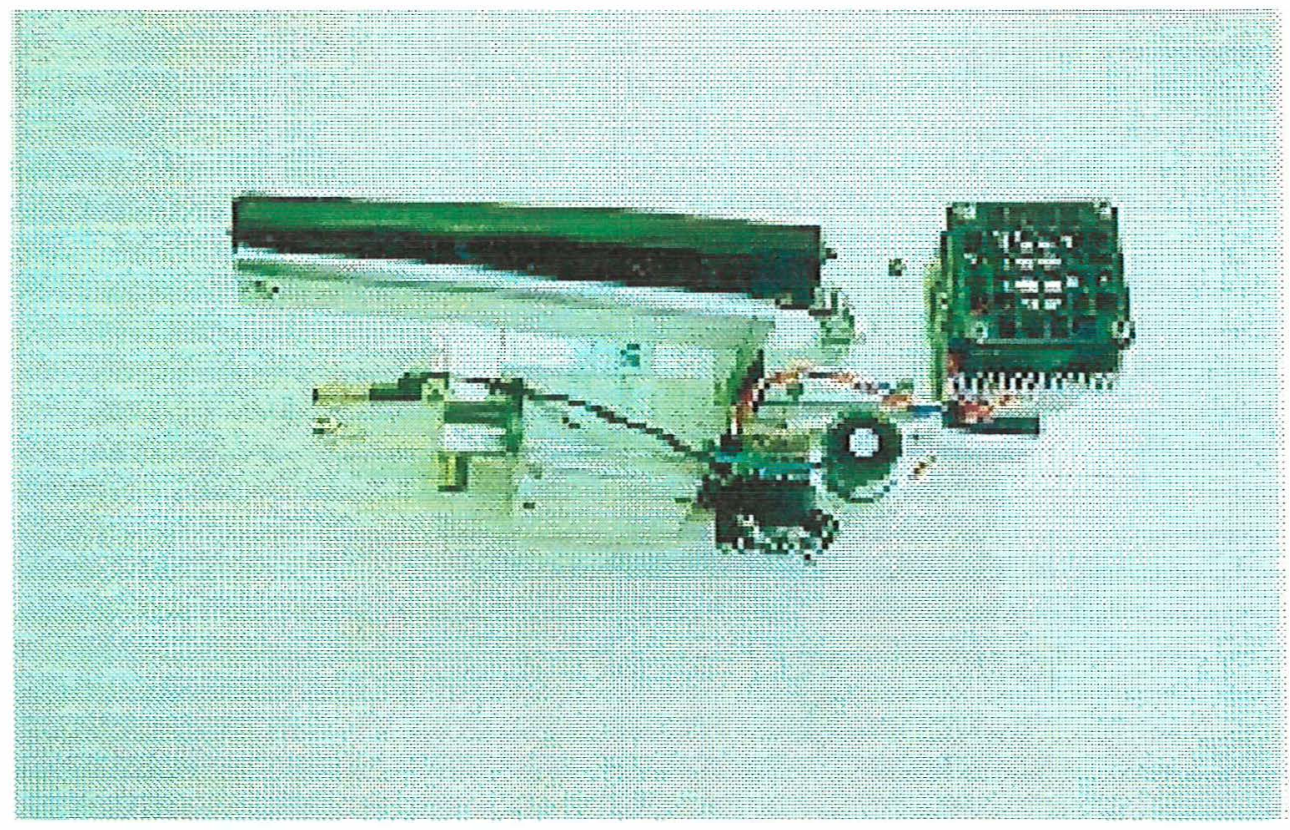

Figura 2 - Sistema LI - 6400, câmara sensora. 
Um fluxo contínuo de ar é succionado a uma taxa conhecida; o ar é homogeneizado e um gradiente na concentração de $\mathrm{CO}_{2}$, na saída da câmara, é determinado por um sensor. A taxa de assimilação de $\mathrm{CO}_{2}$ é expressa como a quantidade de $\mathrm{CO}_{2}$ assimilado ou liberado por unidade de área foliar e tempo, cuja unidade é $\mu \mathrm{mol} \mathrm{CO}_{2} \mathrm{~m}^{-2} \mathrm{~s}^{-1}$.

\subsubsection{Ensaio 1}

Um ensaio preliminar foi realizado para o estabelecimento da intensidade de radiação, à partir da qual não houvesse mais alterações na taxa fotossintética líquida das plantas, sendo este o ponto de máxima eficiência fotossintética.

O ensaio foi realizado em casa de vegetação do Departamento de Ciências Biológicas - ESALQ. Três dos genótipos estudados foram semeados em vasos de 12 litros de capacidade, contendo uma mistura de solo latossolo vermelho escuro peneirado e seco ao ar, vermiculita de textura média e areia grossa, na proporção volumétrica de 3:1:0,5; e adubados conforme recomendações de Quaggio \& Ungaro (1996). Após a germinação, foi feito um desbaste e deixou-se uma planta por vaso.

Decorridos 25 dias após a germinação, quando as plantas apresentavam folhas bem expandidas, foram feitas as curvas de saturação lumínica. Programou-se o aparelho, para que a cada 10 minutos registrasse a taxa assimilatória líquida $(\boldsymbol{A})$ em função das variações na intensidade do fluxo de fótons fotossintéticos (FFF), seguindose uma sequência crescente de FFF : 400,650, 800, 1000, 1350, 1500, 1750 e 2000 $\mu \mathrm{mol} \mathrm{m} \mathrm{m}^{-2} \mathrm{~s}^{-1}$.

$\mathrm{Na}$ determinação das curvas de saturação lumínica foi utilizado o genótipo Morgan - 742. No entanto, na sequência dos experimentos, este foi substituído pelo genótipo BRS 191, por este motivo não será apresentada, adiante, a curva para este genótipo. 


\subsubsection{Ensaio 2}

O ensaio foi delineado em um esquema fatorial $4 \times 2$, com 4 genótipos e 2 tratamentos - COM DOENÇA e SEM DOENÇA, com 4 repetições, totalizando 32 parcelas. Cada parcela teve área de $27 \mathrm{~m}^{2}$, sendo 4 linhas com 30 plantas e espaçamento de $0,90 \times 0,20 \mathrm{~m}$ entre plantas, deixando-se uma planta por cova após o desbaste. Para as avaliações de fotossintese, foram consideradas apenas as 2 linhas centrais. Os blocos foram adubados segundo Quaggio \& Ungaro (1996).

Os tratamentos, com doença e sem doença, foram separados por uma faixa de $15 \mathrm{~m}$, com o intuito de evitar contaminação entre as parcelas, onde foi plantada crotalária, por se tratar de uma cultura não susceptível ao patógeno.

A primeira avaliação da fotossíntese foi iniciada no estádio vegetativo $\left(V_{n}\right)$; a segunda avaliação, em $R_{5.1}$ (10\% das flores do capítulo abertas) para IAC-Uruguai e Rumbosol e em $R_{5.8}$ (80\% das flores do capítulo abertas) para BRS 191 e IAC-larama. Estabeleceu-se o primeiro par de folhas totalmente expandidas como o local das observações, sendo padronizada a borda das folhas como a região a ser utilizada, evitando-se assim as nervuras centrais e descartando-se a possibilidade do equipamento vir a destruir as folhas, em decorrência do manuseio.

Inicialmente foram amostradas as folhas do terço inferior das plantas, pois a doença se desenvolve a partir das folhas baixeiras e vai em direção ao ápice da planta, o capítulo. Escolheu-se, aleatoriamente, uma planta bem desenvolvida e competitiva, em uma das duas linhas centrais das parcelas. A região da folha onde foram feitas as medidas com a câmara de análise do aparelho, foi demarcada a fim de se fazer a leitura sempre no mesmo local, para que pudesse ser calculada a severidade. $A$ área foliar medida foi de $6 \mathrm{~cm}^{2}$, correspondente à área abrangida pela câmara do aparelho.

À medida que a doença foi alastrando pela planta, a primeira folha amostrada foi perdida. Então, passou se para as folhas do terço mediano e repetiu-se o procedimento anterior. Neste ensaio foi amostrado um total de 64 folhas, sendo 32 sadias e 32 doentes. 
Para todas as folhas avaliadas, foi feita uma programação no medidor portátil de fotossíntese, para que registrasse dados a cada minuto, durante 60 minutos. Foi observada uma folha por planta obtendo-se no total 60 observações em cada planta. As medidas foram conduzidas à temperatura ambiente, radiação natural e a concentração de $\mathrm{CO}_{2}$ em condições atmosféricas, sem controle do equipamento.

As medidas foram iniciadas entre 8:30 e $9 \mathrm{~h}$ e concluídas às $17 \mathrm{~h}$, por ser 0 período que compreende a atividade fotossintética das plantas. Neste intervalo de tempo, pode-se observar 8 parcelas por dia. Havendo 4 repetições de cada genótipo por tratamento, intercalou-se as observações entre as parcelas, para que fossem feitas em horários diferentes do dia, para cada genótipo, da maneira como descrito nas Tabelas $1 \mathrm{a}$ e1b.

Tabela 1a. Horário de início das medições na primeira avaliação realizada nas parcelas do Ensaio 1.

\begin{tabular}{|c|c|c|c|c|c|c|c|}
\hline $\mathrm{A} 1$ - & $11: 45$ & A2 - & $10: 50$ & A3 - & 9:00 & A4 - & $9: 55$ \\
\hline B1 - & $15: 20$ & B2 - & $13: 30$ & B3 - & 12: 40 & B4 - & $14: 25$ \\
\hline C1 - & 8: 55 & C2 - & 9: 50 & C3 - & 10: 45 & C4 - & $11: 40$ \\
\hline D1 - & 13: 25 & D2 - & $15: 10$ & D3 - & $14: 20$ & D4 - & $12: 35$ \\
\hline A1 - & $12: 20$ & A2 - & $14: 00$ & A3 - & 13: 10 & A4 - & $14: 50$ \\
\hline B1 - & 9:50 & B2 - & 9:00 & B3 - & $11: 30$ & B4 - & $10: 40$ \\
\hline C1 - & 13: 10 & C2 - & $12: 20$ & C3 - & 14: 50 & C4 - & $14: 00$ \\
\hline D1 - & $11: 30$ & D2 - & $10: 40$ & D3 - & 9: 50 & D4 - & $8: 30$ \\
\hline
\end{tabular}

Tabela 1b. Horário de início das medições na segunda avaliação realizada nas parcelas do Ensaio 1.

\begin{tabular}{|c|c|c|c|c|c|c|c|}
\hline E1 - & $10: 40$ & E2 - & 11: 35 & E3 - & $8: 45$ & E4- & $9: 45$ \\
\hline F1 - & $10: 30$ & F2 - & 9: 30 & F3 - & 12: 20 & F4 - & 11: 25 \\
\hline G1 - & $14: 25$ & G2 - & $13: 25$ & G3 - & 16: 05 & G4 - & $15: 05$ \\
\hline $\mathrm{H} 1-$ & $12: 35$ & H2 - & $15: 20$ & H3 - & $14: 25$ & $\mathrm{H} 4-$ & $13: 30$ \\
\hline E1 - & $12: 20$ & E2 - & $14: 00$ & E3 - & 13: 10 & E4 - & $14: 50$ \\
\hline $\mathrm{F} 1$ - & 9:50 & F2 - & $12: 20$ & F3 - & 11: 30 & F4 - & $10: 40$ \\
\hline G1 - & 13: 10 & G2 - & 9: 00 & G3 - & $14: 50$ & G4 - & 14: 00 \\
\hline $\mathrm{H} 1$ - & $11: 30$ & $\mathrm{H} 2-$ & 10: 40 & H3 - & 9: 50 & H4 - & 9: 00 \\
\hline
\end{tabular}




\subsubsection{Ensaio 3}

O ensaio foi delineado em um esquema fatorial $4 \times 2$, com 4 genótipos e 2 tratamentos - COM DOENÇA e SEM DOENÇA, com 4 repetições, totalizando 32 parcelas. Cada parcela teve área de $27 \mathrm{~m}^{2}$, sendo 4 linhas com 30 plantas e espaçamento de 0,90 × 0,20m entre plantas, deixando-se uma planta por cova após 0 desbaste. Para as avaliações de fotossintese, foram consideradas apenas as duas linhas centrais. Os blocos foram adubados segundo Quaggio \& Ungaro (1996).

Os tratamentos, com doença e sem doença, foram separados por uma faixa de $15 \mathrm{~m}$, com o intuito de evitar contaminação entre as parcelas, onde foi plantado gergelim, uma cultura não susceptivel ao patógeno.

As medidas da fotossintese foram iniciadas com as plantas ainda no estádio vegetativo de crescimento $\left(V_{n}\right)$, e foram sendo feitas diariamente, até o estádio $R_{5.2}$ (fase reprodutiva, segunda fase do florescimento, $20 \%$ das flores abertas) para os genótipos IAC-larama e BRS 191, e estádio $R_{3}$ (fase reprodutiva, segunda fase de alongamento do botão floral) para os genótipos IAC-Uruguai e Rumbosol. Folhas totalmente expandidas do terço mediano das plantas, foram estabelecidas como o local das observações, pois nas folhas do terço inferior haviam sintomas da presença de oídio, e o resultado de medidas nestas folhas estariam mascarando o efeito da alternaria. Foi pulverizado agrotóxico adequado para controle de tal enfermidade.

As folhas foram medidas com o medidor portátil de fotossintese. Segundo foi observado no ensaio 2, todas as medidas foram feitas entre as 9 e $12 \mathrm{~h}$, por que após este horário, os valores registrados apresentavam uma variação muito alta. Não foram feitas medidas programadas, pois também foi observado que, após dois minutos de medida, os valores registrados para fotossintese apresentavam-se bastante estáveis, ao redor da média encontrada. Neste ensaio, as medidas foram registradas ao atingirse valor menor que $1 \%$ de variação registrada pelo aparelho.

Com a finalidade de garantir a intensidade de fluxo de fótons fotossintéticos (FFF) constante durante as avaliações, utilizou-se a fonte de luz artificial do aparelho regulada para $1600 \mu \mathrm{mol} \mathrm{m} \mathrm{m}^{-2} \mathrm{~s}^{-1}$. Foram observadas 8 plantas por parcela, obtendo-se 
no total 256 observações de cada genótipo estudado. Não foi feita avaliação da produção neste ensaio.

\subsubsection{Ensaio 4}

Nas parcelas correspondentes ao tratamento COM DOENÇA do Ensaio 3, foram feitas medidas da taxa fotossintética em plantas que apresentavam folhas lesionadas e folhas sadias. Estas observações foram feitas com o intuito de verificar o desempenho fotossintético de folhas ainda sadias em plantas doentes.

Foram amostradas 4 plantas de cada parcela no tratamento COM DOENÇA; em cada planta, foi medida uma folha sadia e uma folha doente, totalizando 128 medidas. As folhas observadas localizavam-se no terço mediano das plantas e estavam totalmente expandidas. As medidas foram feitas utilizando-se o medidor portátil de fotossintese, com a fonte de luz artificial do aparelho regulada para 1600 $\mu \mathrm{mol} \mathrm{m} \mathrm{m}^{-2} \mathrm{~s}^{-1}$ de FFF.

\subsubsection{Ensaio 5}

Nas parcelas correspondentes ao tratamento SEM DOENÇA do Ensaio 3, foi medida a taxa fotossintética de folhas em diferentes estratos (alturas) da planta: no terço superior, no terço mediano e no terço inferior. Estas observações foram feitas com a finalidade de verificar se havia diferença significativa na taxa fotossintética de folhas em diferentes estratos da planta.

Foram medidas 2 plantas por parcela e 2 folhas em cada estrato da planta, totalizando 96 medidas. As medidas foram feitas utilizando-se o medidor portátil de fotossintese, com a fonte de luz artificial do aparelho regulada para $1600 \mu \mathrm{mol} \mathrm{m} \mathrm{m}^{-2} \mathrm{~s}^{-1}$ de FFF. 


\subsubsection{Avaliação da severidade da doença}

Após a realização das medidas de fotossintese, fotografou-se as folhas com uma câmara digital modelo QV-10 (Casio Ltda.), à $20 \mathrm{~cm}$ de distância.

As imagens foram analisadas com o auxílio do programa WinDIAS, que utiliza um microcomputador com uma mesa de aquisição de imagens para analisá-las. Foi desenvolvido por cientistas, para medir as áreas sadias e doentes de folhas, relatando a porcentagem de área doente em relação à área sadia (Webb et al., 2000).

Diferentemente de um 'scanner', as imagens em video podem ter qualquer magnitude. Assim sendo, após serem fotografadas, todas as folhas avaliadas foram medidas, com uma régua, no sentido do maior comprimento e da maior largura, eliminando-se as distorções no tamanho das áreas a serem medidas. Foram avaliadas áreas sadias e doentes, do local demarcado durante as medições de fotossintese.

A lesão foi definida como sendo o tecido necrosado, de cor marromacinzentado, e os halos cloróticos ao seu redor; todas as outras cores do tecido foliar foram definidas como não sendo parte da lesão visivel. A severidade da doença foi definida como a fração da área foliar, coberta pelas lesões visíveis, medida na câmara do IRGA. Nos dois ensaios, procurou-se medir folhas totalmente expandidas do terço mediano das plantas, que apresentassem lesões características da doença, de acordo com o seguinte procedimento:

a) Selecionou-se a região de interesse na folha (Figura 4). Foram feitas, em seguida, outras duas seleções, a da área sadia e a da área doente (Figura 5). Estas, para serem medidas, foram distinguidas pela diferença na coloração dos tecidos.

b) O programa calcula as áreas e fornece a porcentagem de área doente em relação à área sadia, ou seja, a severidade da doença (Figura 6). Foram considerados, como tecidos doentes, as áreas necróticas das lesões bem como os halos cloróticos ao redor das mesmas. 


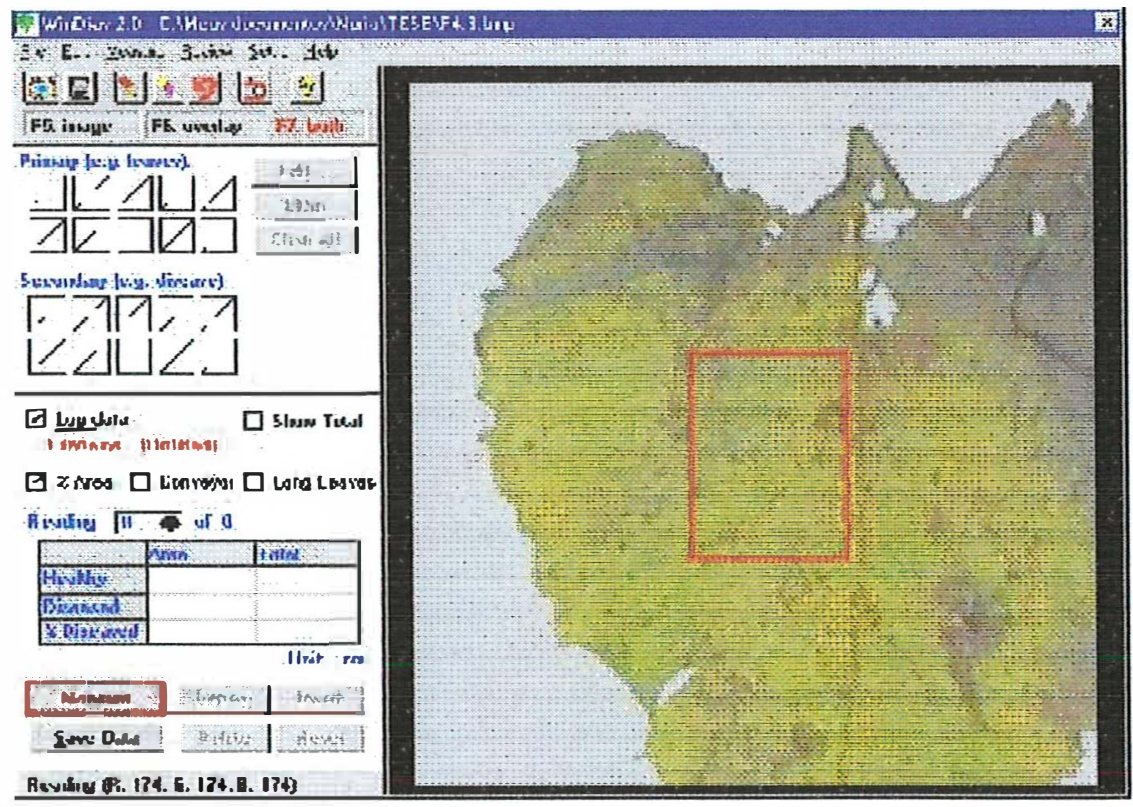

Figura 3 - Tela do programa WinDIAS, seleção da área de interesse na imagem.

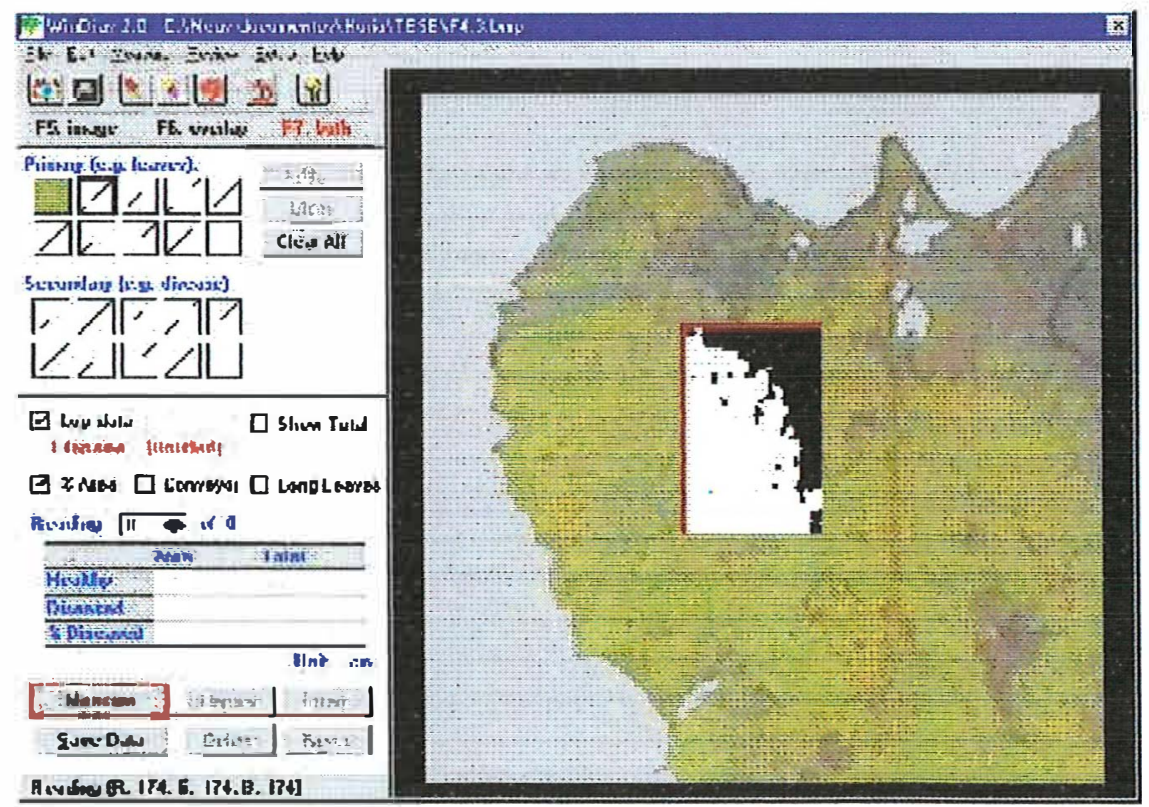

Figura 4 - Tela do programa WinDIAS, seleção das áreas sadia e doente. 


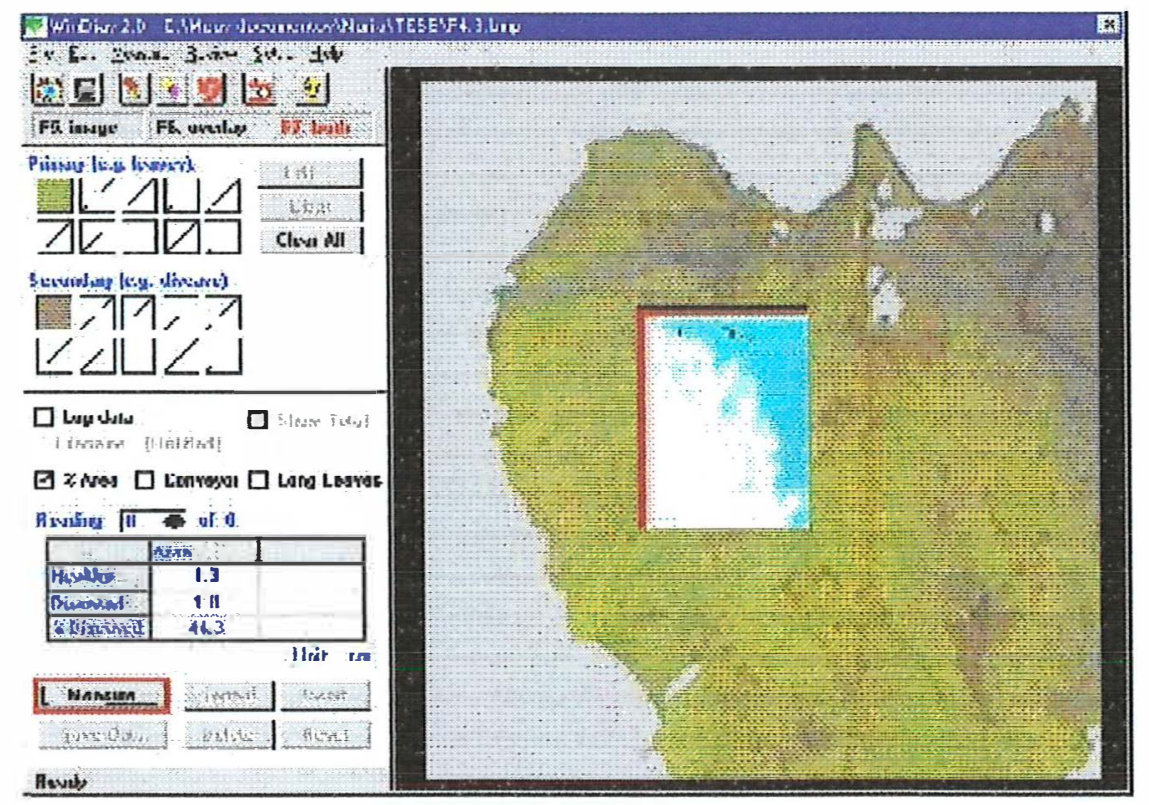

Figura 5 - Tela do programa WinDIAS, cálculo das áreas sadia e doente e porcentagem de área doente em relação à área sadia.

Os valores encontrados para severidade da doença são resultado da média de três repetições de cada folha avaliada. A porcentagem de área doente representa a severidade da doença, e será utilizada na equação de Bastiaans.

\subsection{Análise dos dados}

Quantificou-se o efeito da Alternaria helianthi na fotossintese, pela medida da assimilação de $\mathrm{CO}_{2}$ de folhas individuais de girassol. Os dados experimentais foram usados para relacionar severidade da doença e fotossintese. Ao final de todas as medidas, utilizou-se a estatística descritiva para uma análise preliminar.

A variável taxa de assimilação líquida $(\boldsymbol{A})$ foi relacionada, entre os genótipos e com a severidade da doença, por meio da equação de Bastiaans. Utilizou-se o programa MiniTab, para determinar o parâmetro $\beta$ através de uma análise de regressão, e para as outras análises estatísticas feitas com os dados dos ensaios. 


\section{RESULTADOS E DISCUSSÃO}

\subsection{Ensaio 1}

Através das curvas de resposta à luz determinou-se a saturação lumínica, à partir da qual o sistema começa a perder a eficiência fotossintética. $\mathrm{Na}$ Tabela 2, são apresentados os valores medidos para a taxa de assimilação líquida $(\boldsymbol{A})$ dos genótipos estudados, em função da variação no fluxo de fótons fotossintéticos (FFF).

Para todos os genótipos, à medida que se aumentou a FFF a taxa de fotossintese líquida também aumentou, e o ponto de máxima atividade foi atingido com $1600 \mu \mathrm{mol} \mathrm{m} \mathrm{m}^{-2} \mathrm{~s}^{-1}$ (Figura 7). Com base nestes resultados, o aparelho foi regulado para fornecer esta intensidade luminosa às plantas durante as medidas no ensaio 3.

Tabela 2. Taxa de assimilação líquida $(\boldsymbol{A})$, em $\mu \mathrm{mol} \mathrm{CO}_{2} \mathrm{~m}^{-2} \mathrm{~s}^{-1}$, em função da FFF, para os genótipos estudados.

\begin{tabular}{cccc}
\hline & IAC-larama & IAC - Uruguai & Rumbosol \\
FFF & $\boldsymbol{A}$ & $\boldsymbol{A}$ & $\boldsymbol{A}$ \\
\hline 2000 & 25,3 & 26,9 & 25,3 \\
1750 & 25,1 & 26,3 & 25,5 \\
1500 & 24,7 & 26,9 & 24,7 \\
1350 & 24,5 & 26,0 & 24,9 \\
1000 & 24,4 & 25,3 & 24,8 \\
800 & 23,1 & 23,7 & 22,7 \\
650 & 21,5 & 21,8 & 21,9 \\
400 & 18,5 & 19,2 & 18,3 \\
\hline
\end{tabular}




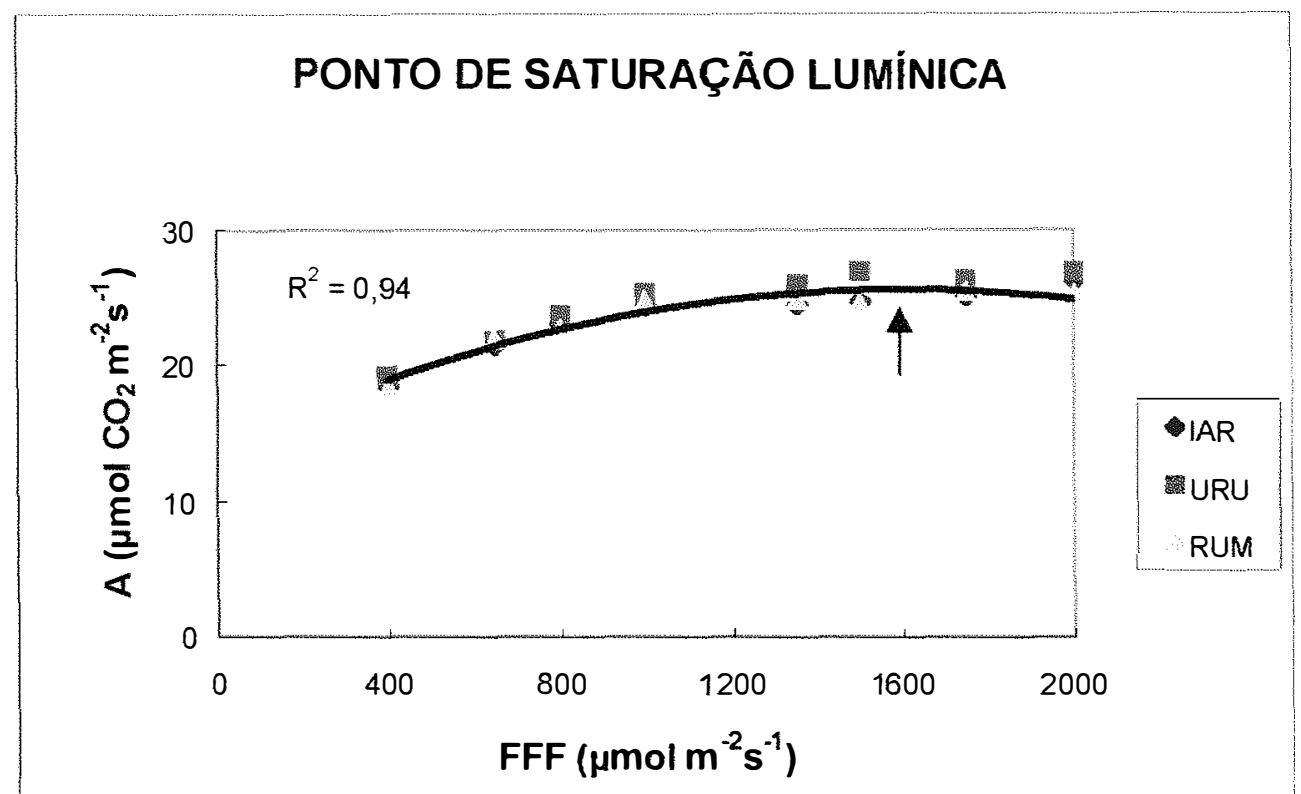

Figura 6 - Curva de resposta à intensidade luminosa para os genótipos de girassol.

\subsection{Ensaio 2}

A taxa fotossintética líquida foi avaliada em folhas sadias e em folhas infectadas com A. helianthi. Os níveis de severidade da doença das áreas avaliadas variaram entre 0 e $35,6 \%$ na primeira avaliação e entre 41,3 e $86,5 \%$ na segunda avaliação (Apêndice 2). Em todos os quatro genótipos estudados houve diminuição significativa na $\boldsymbol{A}$ das folhas doentes, maior que a esperada pela simples redução da área foliar causada pelas lesões. Isto talvez possa ser explicado pela influência do patógeno nas áreas foliares verdes remanescentes.

Nas Tabelas 3a e 3b são apresentados, respectivamente, os valores médios da fotossintese líquida dos tratamentos SEM DOENÇA (Po) e COM DOENÇA (Px), e a redução causada na fotossíntese, para os genótipos de girassol, na primeira e segunda avaliações. 
Tabela 3a. Valores médios da fotossintese líquida dos tratamentos sem doença $(\boldsymbol{P o})$ e com doença $(\boldsymbol{P x})$, e a redução causada na fotossíntese, na avaliação realizada no estádio de crescimento vegetativo, plantio de setembro de 2000.

\begin{tabular}{lcccc}
\hline \multicolumn{1}{c}{ GENÓTIPOS } & Po & $\boldsymbol{P x}$ & $\begin{array}{c}\text { Redução } \boldsymbol{A} \\
(\%)\end{array}$ \\
\hline BRS - 191 & $23,5 \mathrm{a} \quad \mathrm{A}$ & 15,3 a & $\mathrm{B}$ & 35,0 \\
IAC - IARAMA & $19,5 \mathrm{ab} \mathrm{A}$ & 11,0 ab & $\mathrm{B}$ & 43,6 \\
IAC - URUGUAI & $17,4 \mathrm{~b} \quad \mathrm{~A}$ & $7,7 \mathrm{~b}$ & $\mathrm{~B}$ & 56,0 \\
RUMBOSOL & $18,3 \mathrm{ab} \mathrm{A}$ & $9,0 \mathrm{~b}$ & $\mathrm{~B}$ & 51,0 \\
\hline
\end{tabular}

Médias seguidas por uma mesma letra minúscula em cada coluna, não diferem estatisticamente pelo teste de Tukey à 5\%

Média seguidas por mesmas letras maiúsculas na coluna, indicam a não existência de diferenças entre os genótipos, entre plantas sadias e doentes.

Tabela 3b. Valores médios da fotossintese líquida dos tratamentos sem doença $(\boldsymbol{P o})$ e com doença $(\boldsymbol{P x})$, e a redução causada na fotossíntese, na avaliação realizada no florescimento, plantio de setembro de 2000.

\begin{tabular}{|c|c|c|c|}
\hline GENÓTIPOS & Po & $P x$ & $\begin{array}{c}\text { Redução } A \\
(\%)\end{array}$ \\
\hline BRS - 191 & $20,7 \mathrm{ab} A$ & 3,2 a $B$ & 84,5 \\
\hline IAC - IARAMA & $20,5 a b A$ & $2,8 a b \quad B$ & 86,0 \\
\hline IAC - URUGUAI & 22,5 a $A$ & $0,5 \mathrm{~b}$ & 98,0 \\
\hline RUMBOSOL & $19,9 \mathrm{~b} \quad \mathrm{~A}$ & $1,3 a b \quad B$ & 93,5 \\
\hline
\end{tabular}

Médias seguidas por uma mesma letra minúscula em cada coluna, não diferem estatisticamente pelo teste de Tukey à $5 \%$

Média seguidas por mesmas letras maiúsculas na coluna, indicam a não existência de diferenças entre os genótipos, entre plantas sadias e doentes. 
Na Tabela 4 são apresentados, respectivamente, os valores médios da taxa de fotossintese líquida $(\boldsymbol{A})$ e a produção de grãos, para os genótipos de girassol, na segunda avaliação, e a redução da produção no tratamento com doença em relação ao tratamento sem doença.

Tabela 4. Valores médios da taxa de fotossintese líquida $(\boldsymbol{A})$ e a produção de grãos $\left(\mathrm{kg} \mathrm{ha}^{-1}\right)$, para os genótipos de girassol na segunda avaliação.

\section{SEM DOENÇA}

\begin{tabular}{lcl}
\hline GENÓTIPOS & $\boldsymbol{A}$ & $\mathrm{kg} \mathrm{ha}^{-1}$ \\
\hline BRS-191 & $20,7 \mathrm{ab}$ A & $2732 \mathrm{a}$ \\
IAC-IARAMA & $20,5 \mathrm{ab} \mathrm{A}$ & $2380 \mathrm{a}$ \\
IAC-URUGUAI & $22,5 \mathrm{a} \mathrm{A}$ & $2321 \mathrm{a}$ \\
RUMBOSOL & $19,9 \mathrm{~b} \mathrm{~A}$ & $2033 \mathrm{a}$ \\
\hline
\end{tabular}

COM DOENÇA

\begin{tabular}{lccc}
\hline \multicolumn{1}{c}{ GENÓTIPOS } & $\boldsymbol{A}$ & $\mathrm{kg} \mathrm{ha}^{-1}$ & Redução (\%) \\
\hline BRS-191 & $3,2 \mathrm{a}$ B & $2526 \mathrm{a}$ & 8 \\
IAC-IARAMA & $2,8 \mathrm{ab} \mathrm{B}$ & $2056 \mathrm{a}$ & 13 \\
IAC-URUGUAI & $0,5 \mathrm{~b} \mathrm{~B}$ & $1883 \mathrm{a}$ & 20 \\
RUMBOSOL & $1,3 \mathrm{ab} \mathrm{B}$ & $2472 \mathrm{a}$ & --- \\
\hline
\end{tabular}

Média Geral : 2299,84

Coeficiente de variação do experimento : $28,57 \%$

Médias seguidas por uma mesma letra minúscula em cada coluna, não diferem estatisticamente pelo teste de Tukey à $5 \%$

Média seguidas por mesmas letras maiúsculas na coluna, indicam a não existência de diferenças entre os genótipos, entre plantas sadias e doentes.

Apesar da diferença de produção encontrada não ter sido estatisticamente significativa, provavelmente como consequência do CV elevado, existe uma tendência à diminuição desta variável no tratamento com doença. No entanto, a queda na produção ocorrida nos genótipos BRS 191, IAC-larama e IAC-Uruguai, foi bastante alta. Também, não houve correlação entre a produção de grãos e a taxa de 
fotossíntese líquida $(\boldsymbol{A})$ em nenhuma das avaliações realizadas, pelo fato do objetivo deste trabalho ter sido medir a fotossíntese de folhas individuais, e não da planta inteira, o que seria mais recomendável para ser relacionado com a produção.

Na segunda avaliação da taxa fotossintética, as plantas já estavam na fase de maturação fisiológica $\left(R_{9}\right)$, e as folhas do terço inferior em início de senescência. A susceptibilidade dos tecidos de girassol à Alternaria aumenta com a idade; folhas mais velhas são mais susceptíveis que folhas mais jovens e ainda em expansão. Quando se inicia o processo de antese, e os fotoassimilados começam a ser mobilizados para 0 enchimento dos grãos e produção de óleo, perdas do tecido foliar podem resultar em redução na produção maiores que $80 \%$; na fase de maturação de grãos, a taxa fotossintética sofre uma considerável redução e as folhas deixam de crescer em resposta ao acúmulo de amido, (Allen et al., 1981,1982,1983b; Potter \& Breen, 1980; Connor \& Hall, 1997). Deve ser contabilizado, também, o efeito do pólen nas folhas, que pode estimular a germinação dos conídios na superfície foliar e, consequentemente, aumentar a severidade da doença neste estádio de crescimento das plantas.

A menor taxa fotossintética encontrada na segunda avaliação foi resultante principalmente dos seguintes fatores: mobilização dos fotoassimilados para enchimento de grãos; efeito do pólen na germinação dos conídios e aumento significativo no grau da severidade da doença.

Considerando-se que a segunda avaliação foi feita entre o final do florescimento e a maturação fisiológica, e que as parcelas, principalmente as correspondentes ao tratamento com doença, foram naturalmente infectadas por oídio, possivelmente houve uma redução ainda maior na taxa fotossintética medida. Assim, os valores encontrados para $\beta$ na primeira avaliação refletem com mais segurança a influência do patógeno no hospedeiro. A partir dos dados apresentados e da severidade da doença, ajustou-se 0 modelo de Bastiaans, obtendo-se os valores para $\beta$ (Tabelas $5 a$ e $5 b$ ). 
Tabela 5a. Valores encontrados para o parâmetro $\beta$, para o patossistema Girassol $x$ Alternaria. Medidas feitas durante a primeira avaliação, e ajustadas à equação $(P x / P o)=(1-x)^{\beta}$.

\begin{tabular}{lc}
\multicolumn{1}{c}{ GENÓTIPO } & $\beta$ \\
\hline BRS 191 & 4,5 \\
IAC - IARAMA & 4,7 \\
IAC - URUGUAI & 4,4 \\
RUMBOSOL 91 & 3,5 \\
\hline
\end{tabular}

Tabela $5 b$. Valores encontrados para o parâmetro $\beta$, para o patossistema Girassol x Alternaria. Medidas feitas durante a segunda avaliação, e ajustadas à equação $(P x / P o)=(1-x)^{\beta}$.

\begin{tabular}{lc}
\multicolumn{1}{c}{ GENÓTIPO } & $\beta$ \\
\hline BRS 191 & 2,3 \\
IAC - IARAMA & 2,2 \\
IAC - URUGUAI & 4,0 \\
RUMBOSOL 91 & 2,1 \\
\hline
\end{tabular}

Tendo em vista os dados obtidos e analisados, parece existir lesão virtual para o patossistema estudado, Girassol x Alternaria. Diferenças entre os valores de $\beta$ obtidos entre genótipos diferentes, são relatados por Bastiaans (1991), como associadas aos mecanismos pelos quais o patógeno se relaciona com o hospedeiro, atuando no processo fotossintético da folha ou associadas a fatores decorrentes de seleção e melhoramento dos genótipos, para alguma característica agronômica interessante.

Neste ensaio, não foi possivel realizar regressão estatística dos valores obtidos nas duas épocas de avaliação porque os dados foram coletados à partir de uma programação feita no aparelho, para registrar dados no mesmo local da folha durante uma hora. Após o registro, foi feita a média dos valores obtidos para a fotossintese, 
totalizando um número de pontos inferior ao necessário para que o programa realizasse a análise de regressão. Os quadros das Análises de Variância estão apresentados no Apêndice 3.

\subsection{Ensaio 3}

A avaliação da taxa fotossintética, realizada em folhas sadias e infectadas com A. helianthi, encontrou niveis de severidade da doença variando entre 0 e $84,2 \%$ (Apêndice 4). Assim como no Ensaio 2, os 4 genótipos estudados mostraram diminuição significativa na taxa de fotossintese líquida das folhas doentes, maior que a esperada em função da diminuição da área foliar causada pelas lesões; parece haver, portanto, influência negativa do patógeno também nas áreas foliares verdes remanescentes.

A seguir, são apresentados, na Tabela 6 , os valores médios da taxa fotossintética para os tratamentos SEM DOENÇA (Po) e COM DOENÇA (Px), e a redução causada na fotossintese, para os genótipos de girassol.

Tabela 6. Valores médios da $\boldsymbol{A}$ dos tratamentos sem doença $(\boldsymbol{P o})$ e com doença $(\boldsymbol{P} \boldsymbol{x})$, e a redução causada na fotossintese, plantio de junho de 2001.

\begin{tabular}{llllll}
\hline \multicolumn{1}{c}{ GENÓTIPOS } & Po & Px & & $\begin{array}{c}\text { Redução } A \\
(\%)\end{array}$ \\
\hline BRS 191 & 21,7 a & A & 7,3 a & B & 66,3 \\
IAC - IARAMA & 21,0 ab A & 6,4 b & B & 69,5 \\
IAC - URUGUAI & 22,4 a & A & 7,0 a & B & 69,2 \\
RUMBOSOL & 20,4 b & A & 5,0 ab & B & 75,5 \\
\hline
\end{tabular}

Médias seguidas por uma mesma letra minúscula em cada coluna, não diferem estatisticamente pelo teste de Tukey à $5 \%$

Média seguidas por mesmas letras maiúsculas na coluna, indicam a não existência de diferenças entre os genótipos, entre plantas sadias e doentes. 
As avaliações neste ensaio foram feitas até o estádio $R_{52}$ (fase reprodutiva, segunda fase do florescimento, $20 \%$ das flores abertas) para os genótipos IAC-larama e BRS191, e estádio $R_{3}$ (fase reprodutiva, segunda fase de alongamento do botão floral) para os genótipos IAC-Uruguai e Rumbosol. Os dados obtidos foram ajustados à proposição de Bastiaans (1991), sendo as regressões significativas à $5 \%$ de significância (Apêndice $3 c$ e $3 d$ ). A relação entre severidade da doença e a taxa de fotossintese líquida das folhas infectadas foi expressa pelo parâmetro $\beta$ (Tabela 7). Houve diferença significativa entre os tratamentos e entre os genótipos a $5 \%$ de significância (Apêndice 5).

Durante o periodo de avaliação deste ensaio, houve aparecimento de oídio nas folhas do estrato inferior das plantas, tanto sadias quanto infectadas por $A$. helianthi, mas não deve ter influido nas medições uma vez que elas foram feitas nas folhas do terço médio, livres do oídio.

Tabela 7. Valores encontrados para o parâmetro $\beta$, para o patossistema Girassol $x$ Alternaria. Medidas feitas no Ensaio 3 e ajustadas à equação $\left(\boldsymbol{P X} / \boldsymbol{P o}_{0}\right)=(1-\boldsymbol{x})^{\beta}$.

\begin{tabular}{lc}
\multicolumn{1}{c}{ GENÓTIPO } & $\beta$ \\
\hline BRS 191 & 2,3 \\
IAC - IARAMA & 1,4 \\
IAC - URUGUAI & 1,8 \\
RUMBOSOL 91 & 1,8 \\
\hline
\end{tabular}

Comparando-se os valores de $\beta$ obtidos nos dois ensaios, realizados em setembro de 2000 e junho de 2001, houve diferença significativa a 5\% entre as duas épocas de plantio (Apêndice 6).

Os valores de $\beta$ encontrados no ensaio 3 foram menores que os do ensaio 2 , 0 que poderia ser explicado pelo fato de que, no ensaio 2, as horas de insolação e 
pluviosidade foram maiores em função da época do ano (Apêndice 7). A maior insolação poderia estar favorecendo a ocorrência da fotoinibição nas áreas afetadas, e a umidade do ar mais elevada poderia estar intensificando a penetração e esporulação do fungo, que é altamente dependente deste fator.

\subsection{Ensaio 4}

À partir dos resultados deste ensaio padronizou-se as medições para serem feitas sempre no mesmo estrato da planta, evitando-se as folhas baixeiras em função da presença do oídio (estrato inferior), e as folhas não expandidas (estrato superior).

Não houve diferença estatística na taxa de fotossintese liquida obtida nos estratos superior e mediano; o coeficiente de variação entre as medidas feitas no estrato mediano foi menor, as folhas apresentavam-se expandidas e sem a presença de oídio. Dessa forma optou-se por realizar as medições no estrato mediano das plantas (Apêndice 8). Na tabela 8, são apresentados os valores encontrados para $\boldsymbol{A}$, nos três estratos avaliados (superior, mediano e inferior) e o coeficiente de variação dos valores obtidos em cada estrato das plantas.

Tabela 8. Valores médios da $\boldsymbol{A}$ obtidos nos estratos superior, mediano e inferior dos genótipos avaliados e respectivos coeficientes de variação.

\begin{tabular}{lccccc} 
ESTRATOS & \multicolumn{5}{c}{ GENÓTIPOS } \\
\hline & BRS 191 & IAC-larama & IAC-Uruguai & RUMBOSOL & CV \% \\
SUPERIOR & $25,6 \mathrm{a}$ & $22,2 \mathrm{a}$ & $24,6 \mathrm{a}$ & $22,14 \mathrm{a}$ & 7,4 \\
MEDIANO & $22,3 \mathrm{a}$ & $21,1 \mathrm{a}$ & $21,9 \mathrm{a}$ & $20,2 \mathrm{a}$ & 3,5 \\
INFERIOR & $13,2 \mathrm{~b}$ & $14,6 \mathrm{~b}$ & $10,5 \mathrm{~b}$ & $14,8 \mathrm{~b}$ & 12,9 \\
\hline
\end{tabular}

Médias seguidas por uma mesma letra minúscula em cada coluna, não diferem estatisticamente pelo teste de Tukey à $5 \%$ 


\subsection{Ensaio 5}

Este ensaio foi muito importante para o entendimento da interação patógeno $x$ hospedeiro. Na tabela 9 são apresentados os resultados médios da $\boldsymbol{A}$ medida em folhas sadias de plantas correspondentes ao tratamento com doença. Foram avaliadas quatro plantas por parcela; em cada planta foi medida 1 folha sadia e 1 folha doente, totalizando 64 folhas. Houve diferença estatística significativa na taxa fotossintética líquida das folhas avaliadas (Apêndice 9).

Tabela 9. Valores médios da $(\boldsymbol{A})$, para folhas sadias e doentes, medida nas plantas do tratamento com doença.

\begin{tabular}{|c|c|c|c|}
\hline GENÓTIPOS & A - Sadias & $A$ - Doentes & Redução(\%) \\
\hline BRS-191 & $17,25 \mathrm{~A}$ & $8,78 \quad a$ & 49,1 \\
\hline IAC-IARAMA & $17,16 \mathrm{~A}$ & 8,01 ab $A$ & 53,3 \\
\hline IAC-URUGUAI & $16,92 \mathrm{~A}$ & 5,72 ab & 66,2 \\
\hline RUMBOSOL & $16,56 \mathrm{~A}$ & 4,42 & 73,3 \\
\hline
\end{tabular}

Média Geral $=14$

Coeficiente de variação do experimento $=25,7 \%$

Médias seguidas por uma mesma letra minúscula em cada coluna, não diferem estatisticamente pelo teste de Tukey à $5 \%$

Média seguidas por mesmas letras maiúsculas na coluna, indicam a não existência de diferenças entre os genótipos, entre folhas sadias e doentes.

Média seguidas por letras maiúsculas diferentes na coluna, indicam a existência de diferenças entre os genótipos, entre folhas sadias e doentes.

Bhaskaran \& Kandaswamy (1979), citados por Allen at al. (1983), encontraram compostos fenólicos concentrados nas regiões dos halos cloróticos de lesões causadas pela alternaria em girassol, na fase vegetativa de crescimento. Assim, antes de entrar na fase reprodutiva, a presença dos halos cloróticos poderia indicar um mecanismo de resistência parcial à alternaria, onde estariam sendo produzidos os fenóis.

Foi verificado por Livne \& Daly (1966) e Pozsár \& Király (1966), citados por Stangarlin (1999) que, em infecções causadas por fungos, o estimulo da fixação de 
$\mathrm{CO}_{2}$ em folhas sadias de plantas doentes poderia ser uma fonte de carboidratos para a folha colonizada pelo patógeno. A translocação seria direcionada dos tecidos ou folhas sadios para os tecidos e folhas doentes, enquanto a exportação de nutrientes pelas folhas doentes estaria sendo altamente suprimida, havendo 'competição' pelos fotoassimilados entre os tecidos sadios e infectados. Além disso, as folhas ainda sem sintoma da doença, possivelmente estariam sofrendo influência do patógeno também pela difusão de substâncias tóxicas no mesofilo celular, associada a outros fatores relacionados ao metabolismo do carbono.

A menor taxa fotossintética, observada em folhas sadias de plantas de girassol inoculadas com o patógeno $A$. helianthi, indica que a presença do fungo deve causar alguma limitação ao mecanismo fotossintético da planta como um todo. Essa redução pode ainda ter sido provocada pelo metabolismo do próprio fungo, que estaria absorvendo fotoassimilados e produzindo metabólitos secundários, fitotóxicos ao girassol.

Sabe-se que fungos do gênero Alternaria produzem fitotoxinas importantes, que contribuem para o aumento da severidade das doenças que causam. Um dos fitotóxicos mais relatados é a tentoxina produzida pela $A$. tennuis, que interfere no desenvolvimento dos cloroplastos e na inibição do acúmulo de clorofila. O mecanismo de ação envolve a ligação da toxina ao fator de acoplamento $\left(\mathrm{CF}_{1}\right)$ nos cloroplastos, o que ocasiona a inibição da $\mathrm{CF}_{1}$ ATPase e do transporte eletrônico na fotofosforilação (Pascholati, 1995). A mesma ação poderia estar ocorrendo no Complexo $V\left(F_{0} F_{1}\right.$ ATPase) nas cristas mitocôndriais. De acordo com Tal et al. (1985), as fitotoxinas produzidas pela $A$. helianthi são pironas derivadas da radicinina, e o mais importante fitotóxico relatado é a deoxiradicinina; há alguma especulação de que este fitotóxico agiria nos mesmos locais que a tentoxina.

Os cloroplastos produzem ATP e $\mathrm{NADPH}_{2}$ nas membranas dos tilacóides (MT), com a finalidade de serem utilizados nas reações da respiração. As mitocôndrias produzem continuamente ATP a partir da glicólise, para a reposição das proteínas e lipídios da membrana plasmática (MP), com a finalidade de manter sua integridade. No momento em que o patógeno entra em contato com a superfície celular do hospedeiro, inicia-se uma cadeia de alterações em seu metabolismo. Após a adesão e liberação de 
enzimas cutinases e celulases para destruição da parede celular, a estrutura de penetração do patógeno chega aos tecidos parênquimáticos.

Em seguida à infecção, surgem os primeiros sintomas visiveis: necroses com halo clorótico. Essas necroses crescem e coalescem, levando à morte das folhas e de outras partes da planta, chegando aos capítulos e afetando a produção de grãos e de óleo. A fotossíntese vai estar sendo afetada a partir do surgimento de áreas cloróticas, que podem evoluir para necroses, onde ocorre a destruição de cloroplastos e das moléculas de clorofila. Mesmo não sendo medida neste trabalho, é sabido que a respiração entra em desequilíbrio pelo comprometimento das reservas de carbono translocadas de tecidos sadios para tecidos doentes, para suprir as atividades metabólicas do patógeno. Isto pode gerar distúrbios que podem levar a via alternativa Pentose-Fosfato à produção de compostos fenólicos (originados na via do ácido chiquímico), que ficam localizados ao redor das necroses, nos halos cloróticos. É a reação de hipersensibilidade que, pela morte dos tecidos ao redor da área de penetração, tenta não deixar o patógeno atingir outras áreas nos tecidos foliares. Se a infecção ocorrer na planta nos primeiros estágios de desenvolvimento, provavelmente encontrará maior resistência à sua evolução, visto que não foi verificada a presença do referido composto em folhas adultas de girassol.

Em resposta à produção de compostos fenólicos, o patógeno produz uma fitotoxina que pode apresentar muitas atividades. Inicialmente, suprime a expressão do metabolismo secundário do hospedeiro; posteriormente, estaria envolvida com a diminuição da taxa fotossintética porque pode ligar-se ao $C_{1}$ da enzima ATPase nas membranas do tilacóide (MT), inibindo a formação do ATP, que seria utilizado nas reações do ciclo de Calvin no estroma. E finalmente, pode causar aumento da taxa respiratória porque pode ligar-se ao $F_{0}$ do complexo $V$ da enzima ATPase nas cristas mitocôndriais, onde ocorre a maior produção de ATP celular.

Com a produção de ATP mitocôndrial comprometida, a MP não consegue repor as proteínas e lipídios necessários para a manutenção da integridade de sua gelestrutura e a relação de equilíbrio entre ácidos graxos saturados e insaturados é quebrada, havendo rompimento e morte da célula. 
O resultado deste complexo processo fisiológico influencia todo o processo produtivo, porque a diminuição da taxa fotossintética, associada ao aumento da taxa respiratória, tem efeitos indiretos sobre a produção. 


\section{CONCLUSÕES}

Pode-se concluir que, para os genótipos avaliados, as folhas quando infectadas por Alternaria helianthi, apresentam um desempenho fotossintético inferior ao das folhas sadias.

Os valores de $\beta$ encontrados no Ensaio 2 e no Ensaio 3, entre 1,4 e 4,7, indicam que:

- houve redução da taxa fotossintética do tecido verde remanescente das folhas doentes, comprovando que existe lesão virtual para o patossistema Girassol $\times A$. helianthi;

- que as épocas de plantio têm influência sobre a severidade da doença;

- que mesmo apresentando folhas ainda sem lesões, as plantas doentes apresentam comprometimento fotossintético;

- que a produção de grãos é afetada pelo conjunto de alterações ocorridas no hospedeiro após a instalação do patógeno;

- que devem existir diferenças na regulação do metabolismo dos genótipos estudados. 


\section{REFERÊNCIAS BIBLIOGRÁFICAS}

AGRIOS, G. N. Plant pathology. 4. ed. San Diego: Academic Press, 1997. 635 p.

ALLEN, S. J.; KOCHMAN, J. K.; BROWN, J. F. Losses in sunflower caused by Alternaria helianthi in southern Queensland. Australian Journal of Agricultural and Animal Husbandry, v. 21, p. 98-100, 1981.

ALLEN, S. J.; KOCHMAN, J. K.; BROWN, J. F. The control of alternaria blight of sunflowers in eastern Australia. In: INTERNACIONAL SUNFLOWER CONFERENCE, 10., Surfers Paradise. Proceedings, Queensland: ISA Press, 1982. p. 149-151.

ALLEN, S. J.; KOCHMAN, J. K.; BROWN, J. F. Effects of leaf age, host growth stage, leaf injury and pollen on the infection of sunflowers by Alternaria helianthi. Phytopathology, v. 73, p. 896-898, 1983a.

ALLEN, S. J.; KOCHMAN, J. K.; BROWN, J. F. Production of inoculum and field assessment of Alternaria helianthi on sunflower. Plant Disease, v. 67, p. 665-668, 1983b.

BASSANEZI, R. B. Efeito de doenças foliares na eficiência fotossintética do feijoeiro (Phaseolus vulgaris L.), como contribuição na avaliação de danos. Piracicaba, 2000. 233 p. Tese (Doutorado) - Escola Superior de Agricultura "Luiz de Queiroz", Universidade de São Paulo.

BASSANEZI, R. B.; MARTINS, M. C.; GODOY, C. V.; AMORIN, L. Efeito da antracnose na eficiência fotossintética do feijoeiro. Fitopatologia Brasileira, v. 22, n. 4, p. 520524, 1997. 
BASTIAANS, L. Ratio between virtual and visual lesion size as a measure to describe reduction in leaf photosynthesis of rice due to leaf blast. Phytopathology, v. 81, p. 611-615, 1991.

BERGAMIN FILHO, A.; KIMATI, H.; AMORIM, L. (Ed.) Manual de fitopatologia: principios e conceitos. 3 ed. São Paulo: Agronômica Ceres, 1995. 630 p.

BHASKARAN, R.; KANDASWAMY, T. K. Phenol metabolism of sunflower leaves as influenced by $A$. helianthi infection. Journal of Plant Disease Protection, v. 85, p. 108-112, 1979.

CARSON, M. L. Epidemiology and yield losses associated with Alternaria blight of sunflower. Phytopathology, v.75, p. 1151-115, 1985.

CHOU, H. M.; ROLFE, S. R.; SCHOLES, J. D. The effect of Albugo candida on the photosynthetic and carbohydrate metabolism of Arabidopsis thaliana. In: WALTERS, D. R.; SCHOLES, J. D.; BRYSON, R. J.; PAUL, N. D.; MC ROBERTS, N. Physiological responses of plant to pathogens: aspects of applied biology. Warwick: AAB, 1995. p. 149-153.

CONNOR, D. J.; HALL, A. J. Sunflower physiology. In: SCHNEITER, A. A. Sunflower technology and production. Madison: American Society of Agronomy, 1997. p. 113 - 182.

DUDIENAS, C.; UNGARO, M. R. G. ; MORAES, S. A. Alternaria disease development under tropical conditions. Helia, v. 21, n. 29, p. 63-72, 1998.

DUNAWAY, J.M. Water relations of Fusarium wilt in tomato. Physiology Plant Pathology, v.1, p. 537-546, 1971.

ELINGS, A.; ROSSING, W. A. H.; WERF, W. van der. Virtual lesion extension: a measure to quantify the effects of bacterial blight on rice leaf $\mathrm{CO} 2$ exchange. Phytopathology, v. 89. n. 9, p. 789-795, 1999.

GOODMAN, R. N.; KIRÁLY, Z.; WOOD, K. R. The biochemitry and physiology of disease. Columbia: University of Missouri Press, 1986. 433p. 
GOTO, K. Estimating losses from rice blast in Japan. In: SYMPOSIUM AT IRRI, Baltimore, 1963. The rice blast disease: proceedings. Maryland: Jonh Hopkins University Press. p. 195-202.

KEMPENAAR, C.; HORSTEN, P. J. F. M.; SCHEEPENS, P. C. Effects of $A$. caulina on photosynthesis of leaves of Chenopodium album. New Phytology, v. 132, p. 453$457,1996$.

KONG, G. A.; SIMPSON, G. B.; KOCHMAN, J. K.; BROWN, J. F. Components of quantitative resistance in sunflower to $A$. helianthi. Annals of Applied Biology, v. 130 , p. 1-13, 1997.

LEITE, B.; PASCHOLATI, S. F. Hospedeiro: alterações fisiológicas induzidas por fitopatógenos. In: BERGAMIN FILHO, A.; KIMATI, H.; AMORIM, L. (Ed.) Manual de fitopatologia: princípios e conceitos. 3 ed. São Paulo: Agronômica Ceres, 1995. v.1, cap. 21 , p. 393-416.

LIVNE, A.; DALY, J. M. Translocation in healthy and rust-affected leaves. Phytopathology, v. 56, p. 170-175. 1966.

LONG, S. P. ; HALLGREN, J. E. Measurement of $\mathrm{CO}_{2}$ assimilation by plants in the field and in the laboratory. In: HALL, D. O.; SCURLOCK, J. M. O.; BOLHÀRNORDENKAMPF, H. R.; LEEGOOD, R. C. ; LONG, S. P. Photosynthesis and laboratory manual. London: Chapman \& Hall, 1993. p. 129-167.

LUCAS, J. A. Plant pathology and plant pathogens. 3. ed. Oxford: Blackwell Science, 1998. $274 \mathrm{p}$.

MADEIRA, A. C.; CLARK, J. A.; ROSSAL, S. Growth, light interception and disease in field bean ( $V$. faba): the effect of late infection of $A$. fabae. Annals of Applied Biology, v.112, p. 585-595, 1988.

MONTEITH, J. L. Does light limit crop production? In: JOHNSON, C. B. Physiological processes limiting plant production. London: Chapman \& Hall, 1981. cap. 2, p. 23-28. 
MORAES, S. A.; UNGARO, M. R. G.; MENDES, B. M. J. Alternaria helianthi agente causal de doença em girassol. Campinas: Fundação Cargill, 1983. 20 p.

PAUL, M. J.; LAWLOR, D. W.; DRISCOLL, S. P. The effect of temperature on photosynthesis and carbon fluxes in sunflower and rape. Journal of Experimental Botany, v. 41, p. 547-555, 1990.

POTTER, J. R.; BREEN, P. J. Maintenance of high photosynthetic rates during the accumulation of high leaf starch levels in sunflower and soybean. Plant Physiology, v. 66, p. 528-531, 1980.

POZSÁR, B. I.; KIRÁLY, Z. Phloem-transport in rust affected plants and the cytokinindirected long distance moviment of nutrients. Phytopathologische Zeitschrift, v.56, p. 297-309, 1966.

PRASAD, T.; SINGH, B. K. Effect of relative humidity on oil properties of fungal infested sunflower seeds. Biological Bulletin, v. 5, p. 85-88, 1983.

QUAGGIO, J. A. ; UNGARO, M. R. G. Recomendações técnicas de adubação e calagem para o Estado de São Paulo. 2. ed. Campinas: Instituto Agronômico. 1996. 285 p.

ROBB, J.; BRISSON, J. D.; BUSH, L.; LU, B. C. Ultrastructure of wilt syndrome caused by Verticillium dahliae. VII. Correlated light and transmission electromicroscope identification of vessel coatings and tyloses. Canadian Journal of Botany, v. 57 , p. 822-834, 1979.

SACKSTON, W. E. The sunflower crop and disease: progress, problems, prospects. Plant Disease, v. 65, p. 643-648, 1981.

SADRAS, V. O.; QUIROZ, F.; ECHANTE, L.; ESCANDE, A.; PEREYRA, V. R. Effects of Verticillium dahliae on photosynthesis, leaf expansion and senescence of fieldgrown sunflower. Annals of Botany, v. 86, p. 1007-1015, 2000. 
SCHOLES, J. D.; ROLFE, S. A. How do biotrophic pathogens affect the photosynthetic metabolism of their hosts ? In: WALTERS, D. R.; SCHOLES, J. D.; BRYSON, R. J.; PAUL, N. D.; MC ROBERTS, N. Physiological responses of plant to pathogens : aspects of applied biology. Warwick: AAB Press, 1995. p. 91-99.

SENTElHAS, P. C.; PEZZOPANE, J. R. M.; UNGARO, M. R. G.; MORAES, S. A. ; DUDIENAS, C. Aspectos climáticos relacionados à mancha de Alternaria em cultivares de girassol. Fitopatologia Brasileira, v. 21, n. 4, p. 464-469, 1996.

SRINIVAS, T.; RAO, K. C. S.; CHATTOPADHYAY, C. Physiological studies of Alternaria helianthi, the agent of bligjt of sunflower. Helia, v. 20, n. 27, p. 51-57, 1997.

STANGARLIN, J. R. Atividade de ribulose - 1,5 - bifosfato carboxilase (rubisco), clorofilase, B - 1,3 glucanase e quitinase, e conteúdo de clorofila em cultivares de feijoeiro infectados com U. appendiculatus ou P. griseola. Piracicaba, 1999. 119 p. Tese (Doutorado) - Escola Superior de Agricultura "Luiz de Queiroz", Universidade de São Paulo.

TAL, B.; ROBENSON, D. J.; BURKE, B. A.; AASEN, A. J. Phytotoxins from A. helianthi: radicinin, and the structures of deoxyradicinol and radianthin. Phytochemistry, v. 24, n. 4, p. 729-731, 1985.

TZENG, D. D. \& DEVAY, J. E. Physiological responses of G. hirsutum L. to infection by defoliating and nondefoliation pathotypes of $V$. dahliae Kleb. Physiological Plant Pathology, v.26, p. 57-72, 1985.

WAGGONER,P. E.; BERGER, R. D. Defoliation, disease and growth. Phytopathology, v. 77, n. 3, p. 393-398, 1987.

WEBB, N.;JENKINS, D. WinDIAS user manual. Cambridge: Delta-T Devices Ltd, 2000. 85 p. 


\section{APÊNDICES}


Apêndice 1. Croqui do campo experimental dos Ensaios 2, 3, 4 e 5
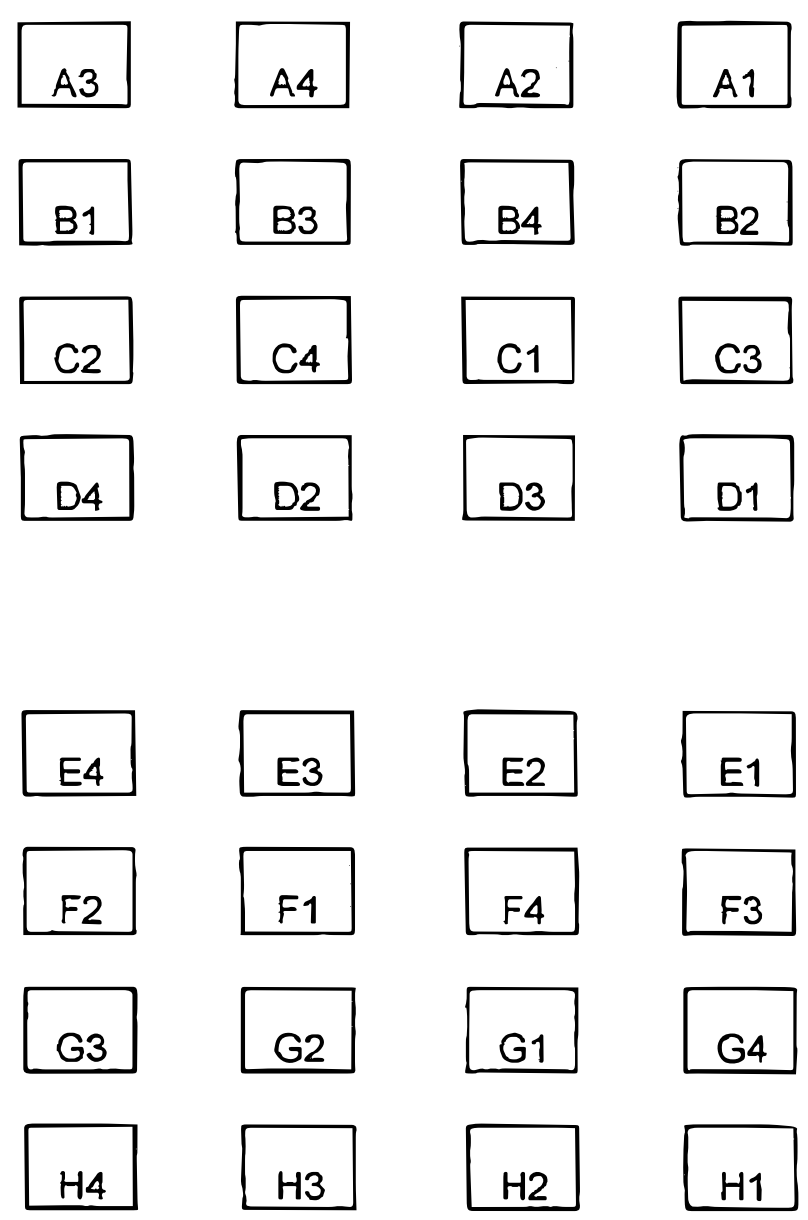

A,B,C,D - parcelas correspondentes ao tratamento SEM DOENÇA

$\mathrm{E}, \mathrm{F}, \mathrm{G}, \mathrm{H}$ - parcelas correspondentes ao tratamento COM DOENÇA

1 - Genótipo BRS-191

2 - Genótipo IAC-larama

3 - Genótipo IAC-Uruguai

4 - Genótipo Rumbosol 
Apêndice 2 . Severidade da doença $(x)$ no Ensaio 2

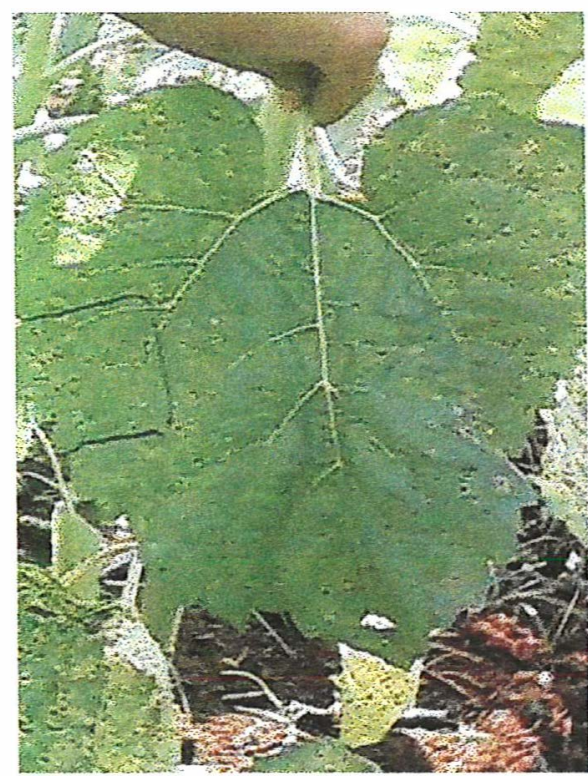

BRS 191 - 20\% área lesionada

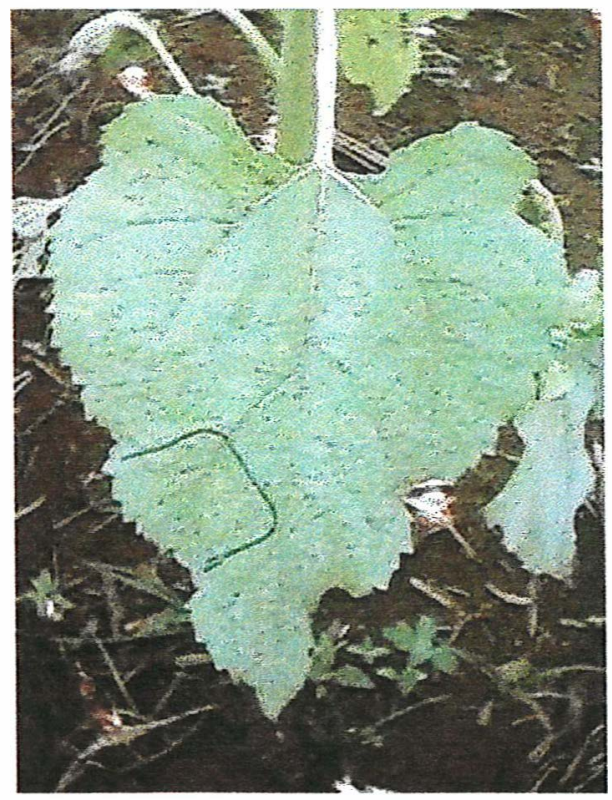

IAC-larama - $60 \%$ área lesionada

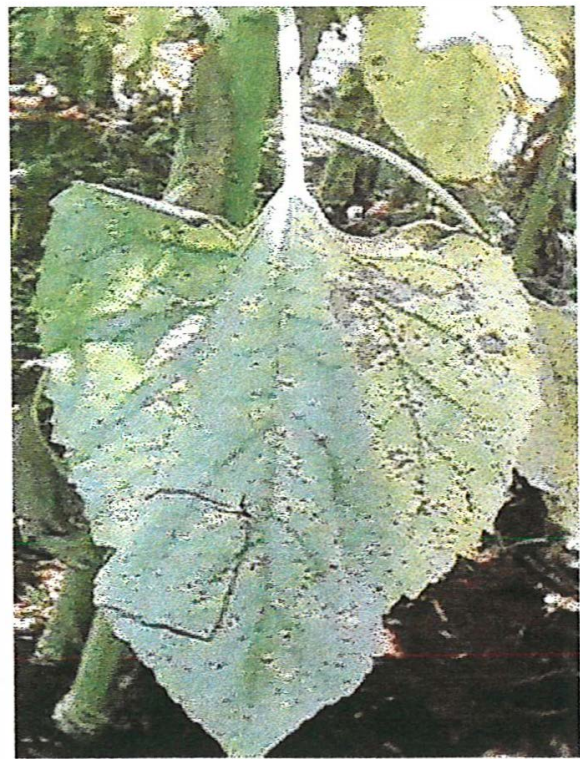

Rumbosol - $70 \%$ área lesionada

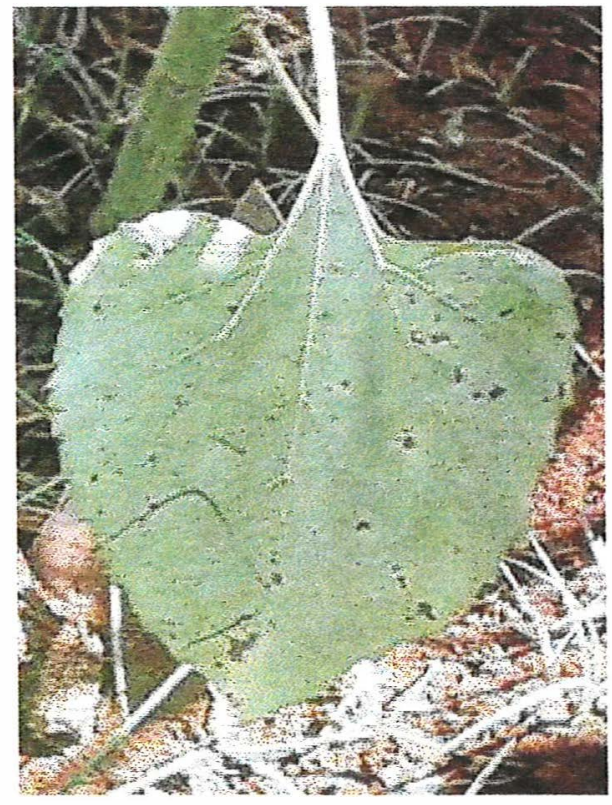

IAC-Uruguai - $45 \%$ área lesionada 


\section{Apêndice 3. Quadros das Análises de Variância do Ensaio 2}

3a. Análise da variância para Produção $\left(\mathrm{kg} \mathrm{ha}^{-1}\right)$

\begin{tabular}{lccl}
\hline Causa Variação & G.L. & F & \\
\hline Alternaria & 1 & 0,32 & n.s. \\
Genótipo & 3 & 1,49 & n.s. \\
Altern. $\times$ Gen. & 3 & 0,19 & n.s. \\
Erro & 21 & & \\
\hline Total & 31 & \\
Média Geral = 2299,84 & & \\
Coeficiente de variação do experimento $=28,57 \%$ &
\end{tabular}

3b. Análise da variância para Taxa Fotossintética líquida $\left(\mu \mathrm{mol} \mathrm{CO}_{2} \mathrm{~m}^{-2} \mathrm{~s}^{-1}\right)$

\begin{tabular}{lccc}
\hline Causa Variação & G.L. & $F$ & \\
\hline Alternaria & 1 & 117,53 & $* \star$ \\
Genótipo & 3 & 4,42 & $* \star$ \\
Altern. x Gen. & 3 & 0,57 & n.s. \\
Erro & 21 & & \\
\hline Total & 31 & &
\end{tabular}

Média Geral $=14,1$

Coeficiente de variação do experimento $=23,71 \%$

3c. Análise da variância para severidade da doença (\%)

\begin{tabular}{lccc}
\hline Causa Variação & G.L. & F & \\
\hline Alternaria & 1 & 100,22 & $* \star$ \\
Genótipo & 3 & 0,78 & n.s. \\
Altern. $\times$ Gen. & 3 & 0,78 & n.s. \\
Erro & 21 & & \\
\hline Total & 31 & & \\
Média Geral $=0,18$ & & \\
Coeficiente de variaçäo d o experimento $=56,5 \% \%$ &
\end{tabular}


Apêndice 4 . Severidade da doença $(x)$ no Ensaio 3

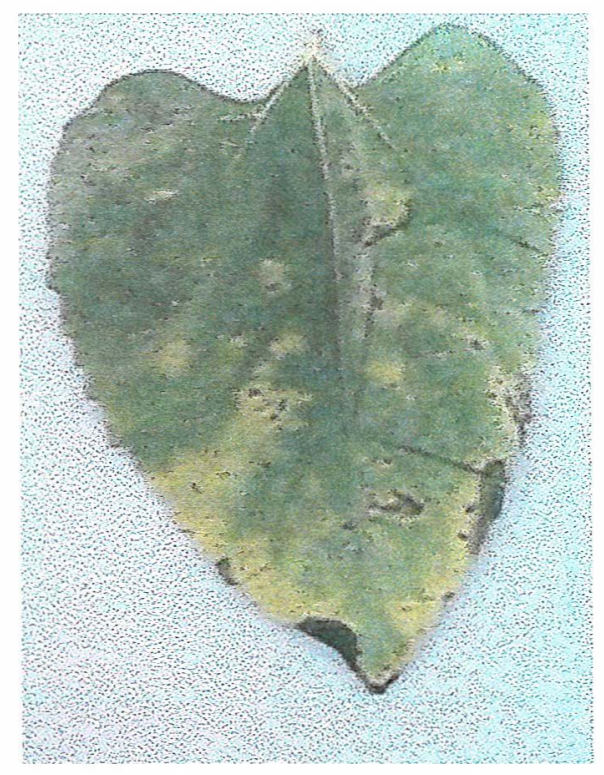

BRS 191 - 40\% área lesionada

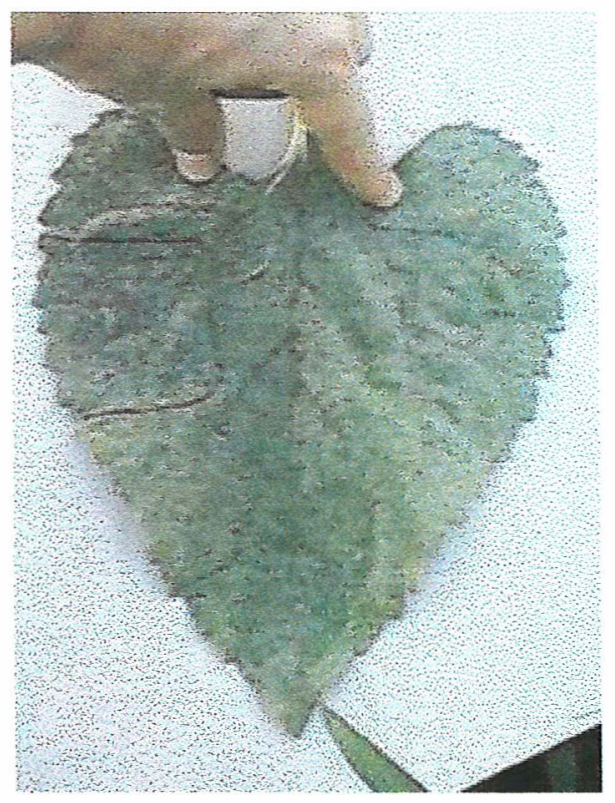

IAC-Uruguai - $65 \%$ área lesionada

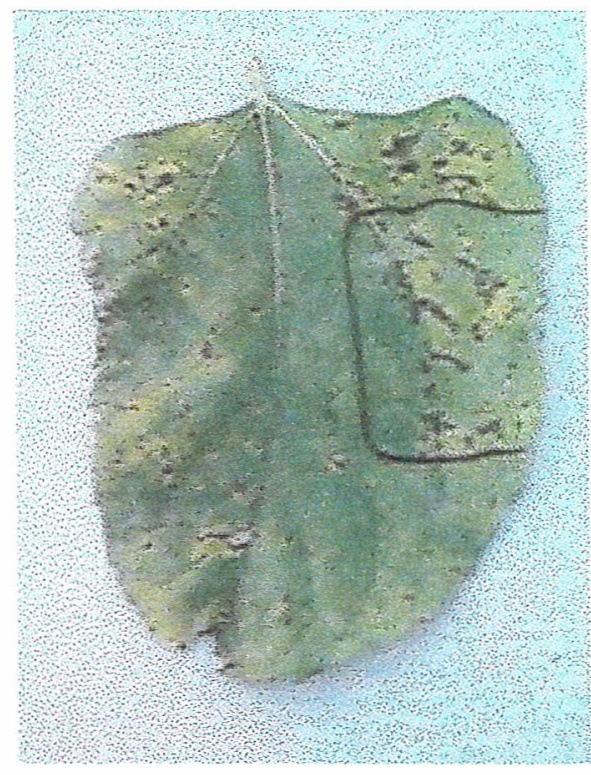

IAC-larama - 80\% área lesionada

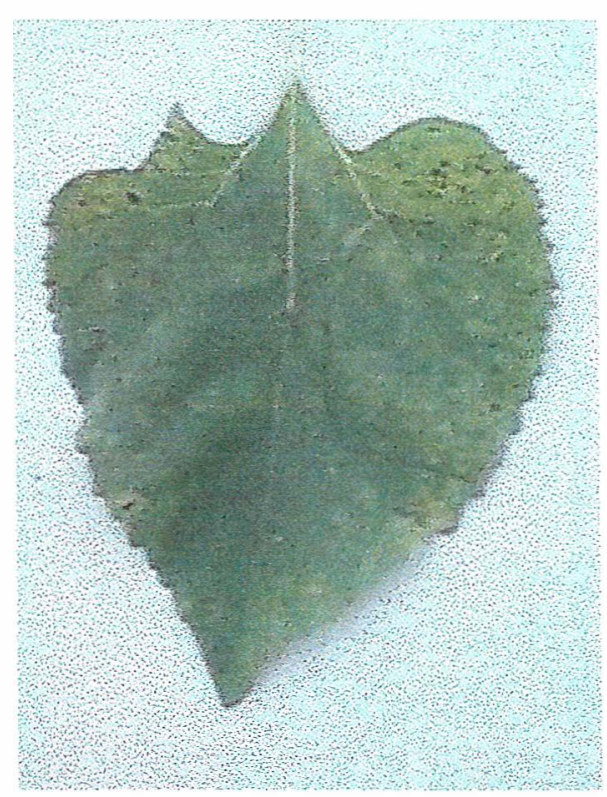

Rumbosol - $25 \%$ área lesionada 
Apêndice 5. Quadros das Análises de Variância e Equações de Regressão do Ensaio 3

5a. Análise da variância para Taxa Fotossintética líquida $\left(\mu \mathrm{mol} \mathrm{CO}_{2} \mathrm{~m}^{-2} \mathrm{~s}^{-1}\right)$

\begin{tabular}{lccc}
\hline Causa Variação & G.L. & F & \\
\hline Alternaria & 1 & 1139,7 & $* \star$ \\
Genótipo & 3 & 4,60 & $* \star$ \\
Altern. $x$ Gen. & 3 & 0,33 & n.s. \\
Erro & 245 & & \\
\hline Total & 255 & & \\
Média Geral $=14$ & & \\
Coeficiente de variação do experimento $=25,7 \%$ &
\end{tabular}

5b. Análise da variância para severidade da doença (\%)

\begin{tabular}{lccc}
\hline Causa Variação & G.L. & F & \\
\hline Alternaria & 1 & 1245,9 & $* *$ \\
Genótipo & 3 & 1,48 & n.s. \\
Altern. $\times$ Gen. & 3 & 1,48 & n.s. \\
Erro & 245 & & \\
\hline Total & 255 & & \\
Média Geral $=0,27$ & & \\
Coeficiente de variação do experimento $=69 \%$ &
\end{tabular}

5c. Equações de regressão

GENÓTIPO BRS - 191

Equação da regressão: Px/Po =0,6695 - 0,6684 $\times(R=0,73)$

Análise da variância

\begin{tabular}{lccc}
\hline Causa Variação & G.L. & F & * \\
\hline Regressão Linear & 1 & 34,2 & \\
Erro & 30 & & \\
\hline Total & 31 &
\end{tabular}




\section{GENÓTIPO IAC - IARAMA}

Equação da regressão : $\mathrm{Px} / \mathrm{Po}=0,7554-0,7671 \times \quad(R=0,78)$

Análise da variância

\begin{tabular}{|c|c|c|c|}
\hline Causa Variação & G.L. & $\mathrm{F}$ & \\
\hline Regressão Linear & 1 & 49,969 & * * \\
\hline Erro & 30 & & \\
\hline
\end{tabular}

\section{GENÓTIPO IAC - URUGUAI}

Equação da regressão: Px/Po $=0,395+0,473 x-0,984 x^{2} \quad(R=0,75)$

Análise da variância

\begin{tabular}{lccc}
\hline \multicolumn{1}{c}{ Causa Variação } & G.L. & F & \\
\hline Reg. Quadrática & 1 & 20,936 & $*$ * \\
Erro & 30 & \\
\hline Total & 31 &
\end{tabular}

\section{GENÓTIPO RUMBUSSOL}

Equação da regressão: $P x / P o=0,3281+0,4136 x-0,875 x^{2} \quad(R=0,64)$

Análise da variância

\begin{tabular}{lccc}
\hline Causa Variação & G.L. & F & \\
\hline Reg. Quadrática & 1 & 11,85 & $*$ \\
Erro & 30 & & \\
\hline Total & 31 &
\end{tabular}


Apêndice 6. Quadros das Análises de Variância - ÉPOCAS DE PLANTIO

Análise da variância

\begin{tabular}{lccc}
\hline Causa Variação & G.L. & F & \\
\hline Genótipo & 3 & 0,39 & n.s. \\
Épocas & 1 & 66,13 & $\star \star$ \\
Erro & 3 & & \\
\hline Total & 7 & & \\
Coeficiente de variação do experimento $=22,3 \%$ &
\end{tabular}


Apêndice 7. Insolação e pluviosidade médias registradas pela Estação Climatológica da Seção de Climatologia Agrícola - IAC, durante os Ensaios 2 e 3.

Ensaio 2 (2000)

\begin{tabular}{ccc} 
& CHUVA $(\mathrm{mm})$ & INSOLAÇÃO $(\mathrm{h})$ \\
\hline AGOSTO & 67,4 & 1,8 \\
SETEMBRO & 76,9 & 3,7 \\
OUTUBRO & 90,3 & 6,3 \\
NOVEMBRO & 276,2 & 5,2 \\
\hline TOTAL NO PERÍODO & 510,8 & 17,0
\end{tabular}

Ensaio 3 (2001)

CHUVA (mm)

INSOLAÇÃO (h)

\begin{tabular}{ccc}
\hline JUNHO & 20,5 & 0,1 \\
JULHO & 11,4 & 0,3 \\
AGOSTO & 27,7 & 2,5 \\
SETEMBRO & 36,1 & 2,0 \\
(1a. Quinzena) & 95,7 & 4,9
\end{tabular}




\section{Apêndice 8. Quadros da Análise de Variância - ESTRATOS FOLIARES DE PLANTAS SADIAS}

Análise da variância

\begin{tabular}{lccc}
\hline Causa Variação & G.L. & F & \\
\hline Genótipo & 3 & 7,10 & $* *$ \\
Estrato & 2 & 72,26 & $* *$ \\
Gen. x Estrato & 6 & 1,47 & n.s. \\
Erro & 77 & & \\
\hline Total & 95 & & \\
Média Geral = 14 & & \\
Coeficiente de variação do experimento $=25,7 \%$ &
\end{tabular}


Apêndice 9. Quadro da Análise de Variância - FOLHAS SADIAS EM PLANTAS DOENTES

Análise da variância

\begin{tabular}{lccc}
\hline Causa Variação & G.L. & F & \\
\hline Alternaria & 1 & 14,79 & $* \star$ \\
Genótipo & 1 & 6,24 & $* \star$ \\
Altern. $\times$ Gen. & 1 & 4,88 & n.s. \\
Erro & 121 & & \\
\hline Total & 127 & & \\
Média Geral $=14$ & & \\
Coeficiente de variação do experimento $=25,7 \%$ &
\end{tabular}

